Article

\title{
Ore Genesis of the Chuduoqu Pb-Zn-Cu Deposit in the Tuotuohe Area, Central Tibet: Evidence from Fluid Inclusions and $\mathrm{C}-\mathrm{H}-\mathrm{O}-\mathrm{S}-\mathrm{Pb}$ Isotopes Systematics
}

\author{
Yong-Gang Sun ${ }^{1,2}$, Bi-Le Li ${ }^{1, *}$, Feng-Yue Sun ${ }^{1}$, Ye Qian ${ }^{1}$, Run-Tao Yu ${ }^{1}$, Tuo-Fei Zhao ${ }^{1}$ and \\ Jun-Lin Dong ${ }^{3}$ \\ 1 College of Earth Sciences, Jilin University, Changchun 130061, China; xg429805791@163.com (Y.-G.S.); \\ sfy@jlu.edu.cn (F.-Y.S.); qianye@jlu.edu.cn (Y.Q.); yurt17@mails.jlu.edu.cn (R.-T.Y.); tuofeiz@126.com (T.-F.Z.) \\ 2 Jilin Institute of Geological Survey, Changchun 130061, China \\ 3 Qinghai Fifth Institute of Geological and Mineral Survey, Xining 810003, China; 120294946@163.com \\ * Correspondence: libl@jlu.edu.cn; Tel.: +86-185-8430-5235
}

Received: 11 April 2019; Accepted: 8 May 2019; Published: 10 May 2019

\begin{abstract}
The Chuduoqu Pb- $\mathrm{Zn}-\mathrm{Cu}$ deposit is located in the Tuotuohe area in the northern part of the Sanjiang Metallogenic Belt, central Tibet. The $\mathrm{Pb}-\mathrm{Zn}-\mathrm{Cu}$ ore bodies in this deposit are hosted mainly by Middle Jurassic Xiali Formation limestone and sandstone, and are structurally controlled by a series of NWW trending faults. In this paper, we present the results of fluid inclusions and isotope $(\mathrm{C}, \mathrm{H}, \mathrm{O}$, $\mathrm{S}$, and $\mathrm{Pb}$ ) investigations of the Chuduoqu deposit. Four stages of hydrothermal ore mineralization are identified: quartz-specularite (stage I), quartz-barite-chalcopyrite (stage II), quartz-polymetallic sulfide (stage III), and quartz-carbonate (stage IV). Two types of fluid inclusions are identified in the Chuduoqu $\mathrm{Pb}-\mathrm{Zn}-\mathrm{Cu}$ deposit: liquid-rich and vapor-rich. The homogenization temperatures of fluid inclusions for stages I-IV are $318-370{ }^{\circ} \mathrm{C}, 250-308^{\circ} \mathrm{C}, 230-294^{\circ} \mathrm{C}$, and $144-233^{\circ} \mathrm{C}$, respectively. Fluid salinities range from $2.07 \mathrm{wt} . \%$ to $11.81 \mathrm{wt} . \% \mathrm{NaCl}$ equivalent. The microthermometric data indicate that the fluid mixing and cooling are two important mechanisms for ore precipitation. The $\mathrm{H}$ and $\mathrm{O}$ isotopic compositions of quartz indicate a primarily magmatic origin for the ore-forming fluids, with the proportion of meteoric water increasing over time. The $\mathrm{C}$ and $\mathrm{O}$ isotopic compositions of carbonate samples indicate that a large amount of magmatic water was still involved in the final stage of mineralization. The $\mathrm{S}$ and $\mathrm{Pb}$ isotopic compositions of sulfides, demonstrate that the ore minerals have a magmatic source. On a regional basis, the most likely source of the metallogenic material was regional potassium-enriched magmatic hydrothermal fluid. Specifically for the Chuduoqu $\mathrm{Pb}-\mathrm{Zn}-\mathrm{Cu}$ deposit, the magmatic activity of a syenite porphyry was the likely heat source, and this porphyry also provided the main metallogenic material for the deposit. Mineralization took place between 40 and $24 \mathrm{Ma}$. The Chuduoqu deposit is a mesothermal hydrothermal vein deposit and was formed in an extensional environment related to the late stage of intracontinental orogenesis resulting from India-Asia collision. The determination of the deposit type and genesis of Chuduoqu is important because it will inform and guide further exploration for hydrothermal-type $\mathrm{Pb}$ and $\mathrm{Zn}$ deposits in the Tuotuohe area and in the wider Sanjiang Metallogenic Belt.
\end{abstract}

Keywords: hydrothermal vein deposit; fluid inclusions; $\mathrm{C}-\mathrm{H}-\mathrm{O}-\mathrm{S}-\mathrm{Pb}$ isotopes; Chuduoqu $\mathrm{Pb}-\mathrm{Zn}-\mathrm{Cu}$ deposit; Tuotuohe area; Sanjiang Metallogenic Belt 


\section{Introduction}

From north to south, the Tibetan Plateau comprises the Songpan-Ganze flysch complex, the eastern Qiangtang Terrane, the western Qiangtang Terrane, the Lhasa Terrane, and the Himalaya (Figure 1a, [1]) separated by the Jinsha, Longmu Tso-Shuanghu, Bangong-Nujiang, and Indus-Yarlung Zangbo suture zones, respectively. These blocks and terranes represent relicts of Tethyan oceanic material of various ages. The Sanjiang Metallogenic Belt is located between the Jinshajiang and Bangonghu-Nujiang sutures along the eastern and northern margins of the Tibetan Plateau and extends for nearly $1500 \mathrm{~km}$ [2]. This belt is an important $\mathrm{Pb}-\mathrm{Zn}$-producing region within the Himalayan-Tibetan metallogenic domain. The Sanjiang Metallogenic Belt evolved as part of a Paleozoic-Mesozoic Tethys archipelagic arc basin over which was sequentially superimposed a Tertiary foreland basin, a strike-slip pull-apart basin, and a thrust-nappe structure that formed during Himalayan orogenesis [3].

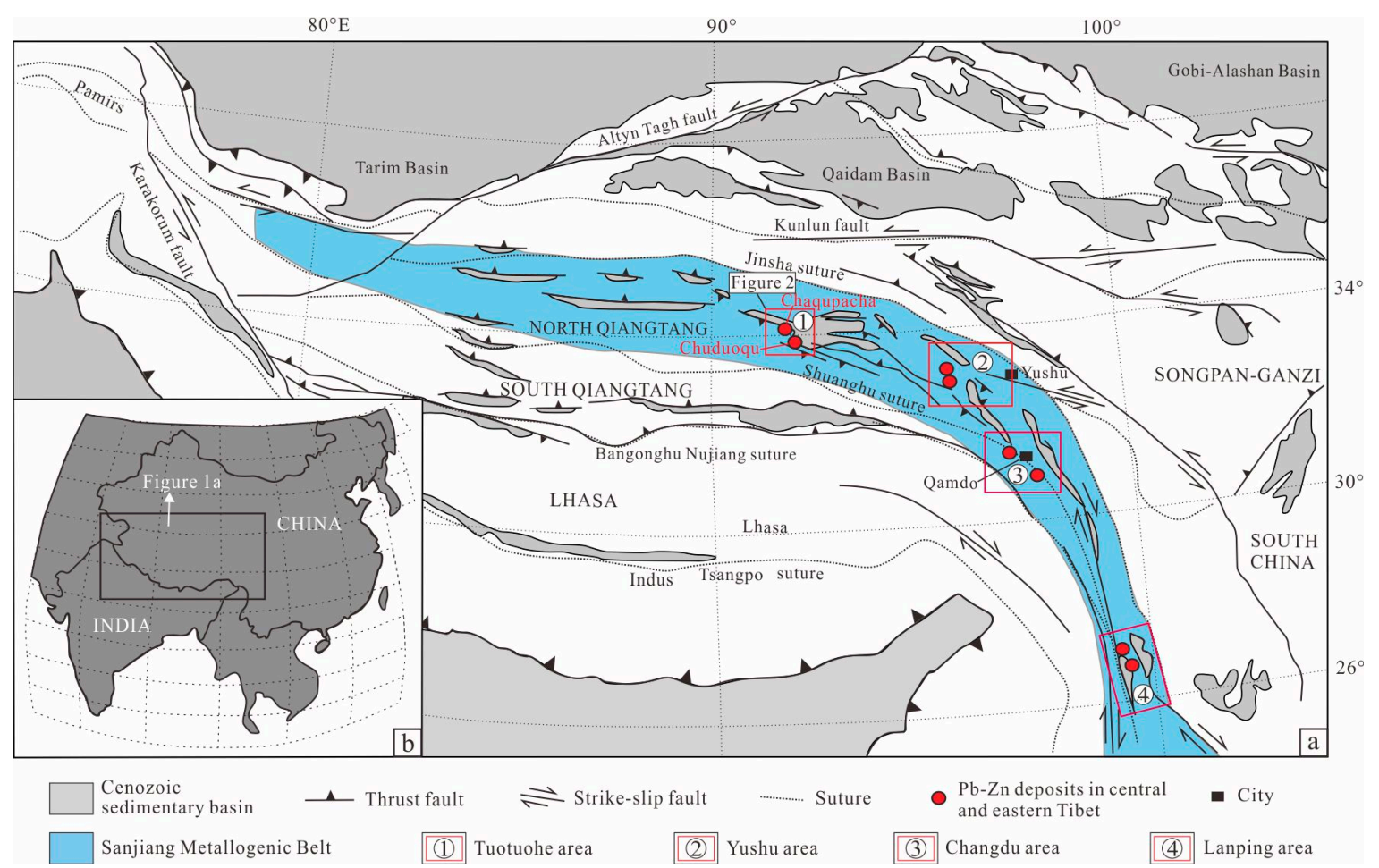

Figure 1. (a) Simplified geological map showing sutures, major structures, and Cenozoic basins in Tibet, modified after Spurlin et al. [4]. The map also shows the locations of the Chuduoqu deposit and other important $\mathrm{Pb}-\mathrm{Zn}$ deposits in the Sanjiang Metallogenic Belt; (b) The inset map shows the location of Tibet within the eastern Asian continent, modified after Liu et al. [5].

The conditions of metallogenesis in the Sanjiang Metallogenic Belt were favorable for the formation of large-scale deposits [6,7]. A series of $\mathrm{Pb}-\mathrm{Zn}$ deposits developed during the Cenozoic, mainly along the margins of Mesozoic-Cenozoic continental basins. The main deposits are distributed from southeast to northwest and include the Jinding and Baiyangping super-large Pb-Zn deposits in the Lanping basin $[8,9]$, the Zhaofayong Pb-Zn deposit in the Changdu Basin [10], and the Dongmozhazhua and Mohailaheng Pb-Zn deposits in the Yushu basin (Figure 1a) [11,12]. The Tuotuohe area, located in the northern part of the Sanjiang Metallogenic Belt, hosts several medium- to low-temperature hydrothermal-vein-type, porphyry-type, MVT and VMS-type deposits [13-15]. Many Pb-Zn deposits and other sites of mineralization have been discovered in the Tuotuohe area, including the Chaqupacha super-large $\mathrm{Pb}-\mathrm{Zn}$ deposit, the Chuduoqu large $\mathrm{Pb}-\mathrm{Zn}-\mathrm{Cu}$ deposit, and the Basihu medium-sized $\mathrm{Pb}-\mathrm{Zn}$ deposit, as well as the Nariniya, Nabaozhalong, and Zhalaxiageyong Pb-Zn deposits (Figure 2). 


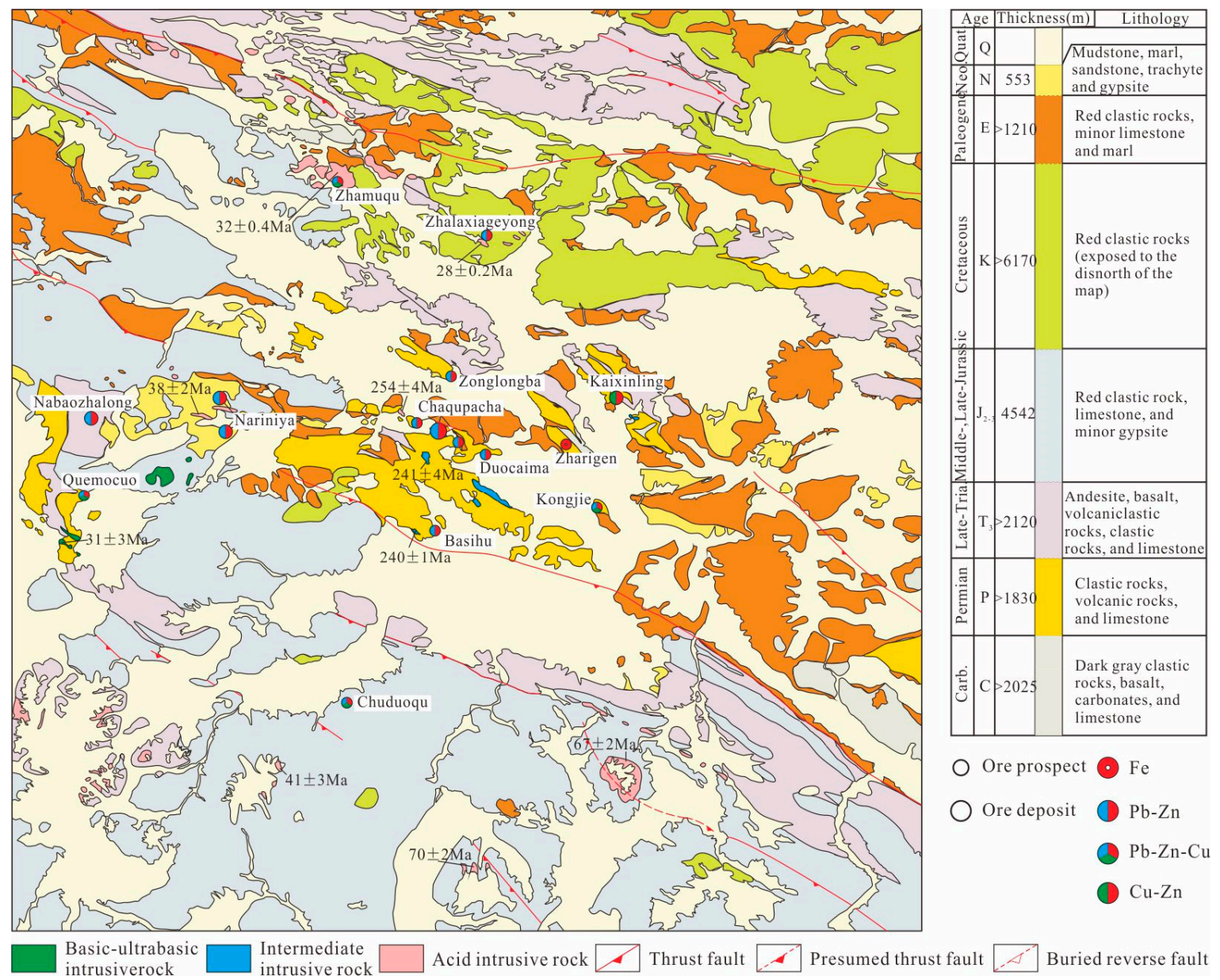

Figure 2. Simplified geological map of the Tuotuohe area, showing stratigraphy, thrust structure, and locations of the Chuduoqu ore deposit and other ore deposits; the map is simplified from six 1:250,000 scale geological maps, modified after [16].

Exploration of the Chuduoqu Pb-Zn-Cu deposit started in 2007. From 2007 to 2011, the Qinghai Fifth Institute of Geological and Mineral Survey carried out work in the northern part of the deposit, where geochemical data indicate favorable conditions for mineralization, and a set of $\sim \mathrm{N}$-S-oriented ore-bearing zones was discovered. These zones show good surface and shallow-subsurface mineralization, weak deep mineralization, and generally unsatisfactory indications for ore-prospecting. In 2011, fracture zone SBIII was discovered, which is the major ore-controlling structural zone formed by the NWW-oriented fault, indicating that ore-prospecting be undertaken on this fracture zone. The $\mathrm{Pb}-\mathrm{Zn}$-rich ore body M9 in fracture zone SBIII was the first such body to be discovered in the hanging wall of the main fault, followed by Cu-Ag ore body M10 and Pb-Ag ore body M11 (Figure 3a) [15]. The Chuduoqu Pb-Zn deposit has estimated metal reserves of 402,547 t Pb, 112,672 t Zn, $9197 \mathrm{t} \mathrm{Cu}$, and $593 \mathrm{t} \mathrm{Ag} \mathrm{[15].}$ 



Figure 3. (a) Geological map of the Chuduoqu Pb-Zn-Cu deposit; (b) Geological cross-section of the M9 ore body. 
Various studies have reported the geological features, mineralization, fluid inclusions, ore-controlling structures, and results of exploration of the Chuduoqu deposit $[13,15]$. Most of these studies have shown that this deposit formed in relation to Cenozoic magmatic hydrothermal activity. The deposit is a mesothermal hydrothermal type that is most likely associated with the intrusion of Cenozoic syenite porphyry dykes. However, the detailed characteristics and mechanisms of the mineralization of the Chuduoqu deposit are poorly constrained, especially when compared with the detailed information available for other Cenozoic $\mathrm{Pb}-\mathrm{Zn}$ deposits in the Tuotuohe area.

The origin, properties, and evolution of the ore-forming fluids, as well as the genesis of the Chuduoqu deposit, are still not fully understood, which limits our overall understanding of the genesis of hydrothermal vein-type $\mathrm{Pb}-\mathrm{Zn}$ mineralization in the region. Using field observations and petrographic studies, we investigated the ore-controlling structures, the composition and characteristics of fluid inclusions, and the stable (C-H-O-S) and radiogenic $(\mathrm{Pb})$ isotope systematics of the Chuduoqu $\mathrm{Pb}-\mathrm{Zn}-\mathrm{Cu}$ deposit. In this paper, we report the results of our study, discuss the characteristics of the mineralizing fluids and metal sources as well as the mechanisms of mineralization, and constrain the genesis of the deposit. In doing so, we provide an important basis for understanding the Chuduoqu $\mathrm{Pb}-\mathrm{Zn}$-Cu deposit and similar deposits in the Tuotuohe area. Our findings should prove valuable for prospecting in the Tuotuohe area and in the Sanjiang Metallogenic Belt.

\section{Geological Background}

The Chuduoqu $\mathrm{Pb}-\mathrm{Zn}-\mathrm{Cu}$ deposit is located in the Tuotuohe area in the northern part of the Sanjiang Metallogenic Belt, central Tibet (Figure 1, [17]). The Tuotuohe area is positioned on the margin of the northern Qiangtang Terrane between the Jinsha River suture zone and the Longmucuo Shuanghu suture zone $[6,15,16]$. The oldest rocks in the Tuotuohe area are Carboniferous clastic and carbonate sediments that are thought to have formed in a passive continental margin setting (Figure 2, [18]); the Permian to Triassic units consist mainly of marine carbonate, clastic, and volcanic rocks. Recent studies of Permian magmatic rocks in the Yushu area have suggested that these units were deposited in a continental-margin-arc setting associated with northward subduction of the Shuanghu oceanic plate between ca. 275 and $248 \mathrm{Ma}$ [19]. Lower and Middle Triassic rocks are absent from the area, meaning that the Upper Triassic rocks unconformably overlie the underlying units. During the Late Triassic, the Tuotuohe area was in a subduction setting involving the southward subduction of the Jinsha oceanic plate [20].

Lower Jurassic rocks are absent from the study area (Figure 2, [16,21]; Middle to Upper Jurassic units in the area consist of clastic and carbonate rocks of (from bottom to top) the Qumocuo, Buqu, Xiali, Suowa, and Xueshan Formations [22]. During the Cretaceous, the Tuotuohe area entered a continental sedimentary stage, when thick successions of clastic deposits were laid down. The Cenozoic units comprise terrigenous clastic and carbonate rocks of the Eocene Tuotuohe Formation, the Eocene-Oligocene Yaxicuo Formation, and the Miocene Wudaoliang Formation $[18,23,24]$, which are exposed mainly in the northern part of the Tuotuohe area (Figure 2).

The Tuotuohe area contains a large-scale thrustnappe structure and strike-slip system as a result of India-Eurasia collisional orogenesis during the Cenozoic [2,9]. The thrustnappe structural belt comprises a series of NWW-trending thrust faults and folds, most of which dip to the southwest [25]. The large-scale thrustnappe in the Tuotuohe area underwent two main episodes of thrusting, one at around 52-42 Ma and the other at around $24 \mathrm{Ma}$ [25]. Between these two episodes, strike-slip activity developed with the formation of a series of strike-slip fault systems [26].

Magmatic activity in the Tuotuohe area started during the late Paleozoic and ended during the Cenozoic. The magmatism was characterized by relatively weak intrusive and strong volcanic activity. Volcanic rocks are widespread at a regional scale. These volcanic rocks comprise Permian basaltic andesite interlayered with basalt; Late Triassic andesite, basalt, and pyroclastic rocks; and Cenozoic trachyte. The Cenozoic volcanic rocks are distributed mostly around the locality of Nariniya and dated at 45-22 Ma [27-29]. 
Magmatic intrusions are widely dispersed, with numerous igneous rock outcrops, but the total area covered by these rocks is quite small. Magmatic rocks include those formed during the Indosinian, Yanshanian, and Himalayan periods. Late Permian-early Triassic syenites and diorite bodies are found in the Chaqupacha deposit [30], and Middle Triassic diorite is present in the Basihu mine [31]. Late Cretaceous granites occur in the Longyala and Munai areas of the Tanggula mountains [32]. Paleogene olivine gabbro-diabase has been discovered in the Quemocuo mining area (Figure 2, [33]), and Cenozoic porphyry bodies have been discovered in the Zhamuqu, Nariniya, Zhalaxiageyong, and Saiduopugangri areas [13,32,34]. The Cenozoic volcanic rocks and granites mentioned above consist predominantly of shoshonitic to high-K calc-alkaline rocks and were formed in a geodynamic setting of crustal shortening, thickening and melting [27-29,32,35]. Their occurrence and ages are supporting evidence for Cenozoic crustal shortening and uplift of the plateau in the study area.

\section{Ore Deposit Geology}

Rocks exposed in the studied mining area include those of the Middle Jurassic Buqu and Xiali formations, the Upper Jurassic Suowa Formation, and Quaternary deposits (Figure 3a). The Middle Jurassic Buqu Formation $\left(\mathrm{J}_{2} b\right)$ is composed predominantly of light-gray to dark-gray limestone, with purple-red and gray argillaceous siltstone and quartz-feldspar sandstone. This formation is rich in marine fossils and is distributed primarily in the southwestern part of the mining area. The Buqu Formation rocks strike at $110-130^{\circ}$, dip at $30-70^{\circ}$ to the NNE, and conformably overlie the Upper Xiali Formation $\left(\mathrm{J}_{2} x\right)$. The Middle Jurassic Xiali Group $\left(\mathrm{J}_{2} x\right)$ is an important ore-bearing group in the study area and consists of the following three lithological sections: (a) the lower section comprises blue-gray crystalline limestone, purple-red muddy siltstone intercalated with purple-red feldspar debris sandstone, and gray feldspathic quartzitic sandstone; (b) the middle section has a lithological association of purple-red feldspathic lithic quartz sandstone interbedded with bioclastic crystalline limestone; and (c) the upper section comprises purple-red feldspar arkose intercalated with gray-green feldspathic quartzitic sandstone. Sedimentary rocks of the Xiali Formation $\left(\mathrm{J}_{2} x\right)$ are distributed primarily in the central part of the mining area. In the northern-central part of the mining area, they strike at $170-200^{\circ}$ and dip at $30-70^{\circ}$ to the east, and in the southern-central part, the beds strike at $130-160^{\circ}$ and dip at $30-70^{\circ}$ to the NE. The Xiali Formation conformably underlies the Upper Suowa Formation $\left(J_{3} s\right)$. The Upper Jurassic Suowa Group $\left(J_{3} s\right)$ is distributed mainly in the eastern part of the mining area. The lower part of this group consists of gray-green calcareous siltstone and mudstone intercalated with biological calcareous siltstone, interbedded with thick layers of muddy crystal limestone, whereas the upper part comprises thick layers of dark-gray muddy crystalline limestone interbedded with thin layers of muddy crystalline limestone. The Suowa Group rocks strike at $110^{\circ}$ and dip at $30-50^{\circ}$ to the east.

The studied mining area is characterized by NWW- and N-trending faults. The NWW-trending faults have four associated fracture zones: SBIII, SBIV, SBV, and SBVI. Of these, fracture zone SBIII (Figure $3 \mathrm{~b}$ ) is the main ore-controlling fracture zone in the area and measures $1000 \mathrm{~m}$ in length and 200-300 $\mathrm{m}$ in width, strikes at $120-135^{\circ}$, and dips at $65-75^{\circ}$ to the SSW. A series of parallel secondary faults are developed in the hanging wall of the main fault and are associated with fracture zones SBIV, SBV, and SBVI. A second group of faults trends N-S and occurs in the footwall of fracture zone SBIII. These N-trending faults have formed several fracture zone structures, including SBI and SBII.

The intrusive rocks in the Chuduoqu mining area include syenite porphyry veins, diabase veins, and fine-grained granite dykes, syenite porphyry veins are oriented $\mathrm{NE}$ to $\mathrm{E}$ and $\mathrm{NW}$, diabase veins are oriented E, fine-grained granite dykes are oriented NE (Figure 3a). Syenite porphyry veins have been identified in boreholes. These veins occur in the rocks of the Xiali Formation $\left(\mathrm{J}_{2} x\right)$ and show strong alteration, mainly baritization and limonitization, as well as carbonation and silicification. The contact zone of the syenite porphyry with the host rocks of the Xiali Formation $\left(\mathrm{J}_{2} x\right)$ is highly mineralized, with the development of massive, vein-like, and disseminated pyrite, chalcopyrite, and galena (Figure $3 b$ ). Locally, crystal lithic tuff overlies the Xiali Group $\left(\mathrm{J}_{2} x\right)$ across an unconformity (Figure $3 \mathrm{~b}$ ). The U-Pb 
age of the crystal lithic tuff is $68.3 \pm 0.7 \mathrm{Ma}$ (unpublished data) and was erupted prior to the onset of mineralization.

The mineralization in the ore bodies is most enriched in and around the intersections of secondary faults (including fracture zones SBIV, SBV and SBVI) with the main fracture zone SBIII. There are six main mineralized alteration zones in the mining area. Eleven polymetallic ore bodies have been identified, including four Pb-Zn-Ag ore bodies (M1, M5, M7, and M9), four Pb-Ag ore bodies (M2, M3, $\mathrm{M} 4$, and M11), one $\mathrm{Pb}-\mathrm{Cu}-\mathrm{Ag}$ ore body (M8), one $\mathrm{Cu}-\mathrm{Ag}$ ore body (M10), and one $\mathrm{Pb}$ ore body (M6) (Figure 3a). The main ore-body-hosting rocks of the Chuduoqu deposit are those of the Xiali Formation $\left(\mathrm{J}_{2} x\right)$, chiefly cataclastic micritic silty limestone and cataclastic quartz-feldspar sandstone. Of the eleven identified ore bodies, six are oriented $\sim \mathrm{N}-\mathrm{S}$ and five are oriented NWW. The six approx N-S-trending ore bodies (M1-M6) occur in N-oriented fracture zones as layers and veins. These ore bodies have lengths of $150-1350 \mathrm{~m}$ and thicknesses of $4-16 \mathrm{~m}$, dip at $42-62^{\circ}$ to the SE, and host good quality surface mineralization but poor discontinuous mineralization at depth. The five NWW-trending ore bodies are distributed in NWW-oriented fractured zones.

In the Chuduoqu Pb-Zn-Cu deposit, the geology and metal resources of ore bodies M1, M2, M8, M9, and M10 have been investigated (Table S1), whereas the resources of the remaining six ore bodies remain unknown. The main ore body, M9, occurs in the altered fracture zone SBIII, which is the main ore-controlling structure. Ore body M9 is layered, extends for more than $500 \mathrm{~m}$, varies in thickness from 3.0 to $24.7 \mathrm{~m}$, and dips at $20^{\circ}$ to the south. This body contains an average $\mathrm{Pb}$ grade of $2.22 \%$ (locally reaching $21.13 \%$ ), an average $\mathrm{Zn}$ grade of $1.41 \%$ (locally up to $8.69 \%$ ), and an average Ag grade of $49.5 \mathrm{~g} / \mathrm{t}$ (locally up to $220 \mathrm{~g} / \mathrm{t}$ ) (Table S1), indicating very good prospecting potential. The degree of host-rock fragmentation in the main fracture zone of ore body M9 varies greatly, with the alteration and mineralization being strongest in regions of highly fractured limestone and sandstone, and weakest in regions of weak host-rock fragmentation.

The ore minerals of the Chuduoqu $\mathrm{Pb}-\mathrm{Zn}-\mathrm{Cu}$ deposit include specularite, magnetite, pyrite, chalcopyrite, bornite, tetrahedrite, pearceite, galena, sphalerite, limonite, malachite, and azurite and the gangue minerals include quartz, calcite, dolomite, barite, sericite, chlorite, and epidote. The ores show mainly xenomorphic granular texture, with subordinate idiomorphic-hypidiomorphic granular texture. In addition, the ores exhibit cataclastic and metasomatic characteristics. The ores show mainly block and vein structures, as well as local disseminated structures. Hydrothermal alteration is widespread in the Chuduoqu $\mathrm{Pb}-\mathrm{Zn}-\mathrm{Cu}$ deposit, with the most intensive alteration occurring in and around the mineralized $\mathrm{Pb}-\mathrm{Zn}-\mathrm{Cu}$ veins. The key components of alteration assemblages include silicification, chloritization, epidotization, sericitization, carbonation, and baritization. Distinct episodes of hydrothermal alteration are recognized: an early episode of silicification, three intermediate episodes (baritization, phyllic and propylitic), and a late carbonatization. Silicification is the most widespread alteration type in the Chuduoqu $\mathrm{Pb}-\mathrm{Zn}-\mathrm{Cu}$ deposit, which coexists with minor early precipitated specularite (Figure 4a). Silicification was overprinted by baritization and phyllic alteration, which consists of barite, quartz and sericite. Baritization and phyllic alteration appear closely related to $\mathrm{Cu}$ metal sulfides deposition (Figure 4c,d). Phyllic alteration was overprinted by propylitic alteration, characterized by an assemblage of chlorite, epidote, and quartz. Propylitic alteration appears closely related to base metal sulfides deposition (Figure $4 \mathrm{~d}$,e). The final stage of hydrothermal alteration is carbonatization, which overprinted all the previous alteration types coexisting with minor pyrite. In addition, there is no obvious spatial zonation of various hydrothermal alteration types, in most cases, the alteration assemblages are superimposed upon one another.

Based on field observations, mineral assemblages, and crosscutting relationships (Figure 4), we divided the mineralization history of the deposit into a hydrothermal mineralization phase (which is subdivided into four mineralization stages) and a supergene phase. The characteristics of the mineral associations in the four hydrothermal stages are as follows (Figure 5). 


\subsection{Quartz-Specularite Ore (Stage I)}

In this stage, specularite ore is the main metallic mineral and occurs as needle-like crystals with idiomorphic-hypidiomorphic texture. The mineral assemblage of this stage is quartz + specularite, cut by late-stage quartz-barite-chalcopyrite veins (Figure 4a).

\subsection{Quartz-Barite-Chalcopyrite (Stage II)}

In this stage, the gangue minerals are mainly quartz and barite, and the ore minerals are mainly pyrite and chalcopyrite (Figure 4c). Small amounts of bornite and tetrahedrite are found, mostly with idiomorphic-hypidiomorphic texture. The mineral assemblage is quartz + barite + pyrite + chalcopyrite + bornite + tetrahedrite (Figure $4 \mathrm{~g}, \mathrm{~h}$ ). This stage is the main metallogenic stage for $\mathrm{Cu}$.

\subsection{Quartz-Polymetallic Sulfide Stage (Stage III)}

This stage is the main stage of deposit formation. The gangue minerals are dominated by quartz, and the metallic minerals are chiefly galena, sphalerite, pyrite, and minor pearceite and chalcopyrite (Figure 4d), mostly showing idiomorphic and hypidiomorphic textures. The mineral assemblage is quartz + galena + sphalerite + pyrite + chalcopyrite + pearceite (Figure 4e,i). This stage is the main metallogenic stage of $\mathrm{Pb}$ and $\mathrm{Zn}$.
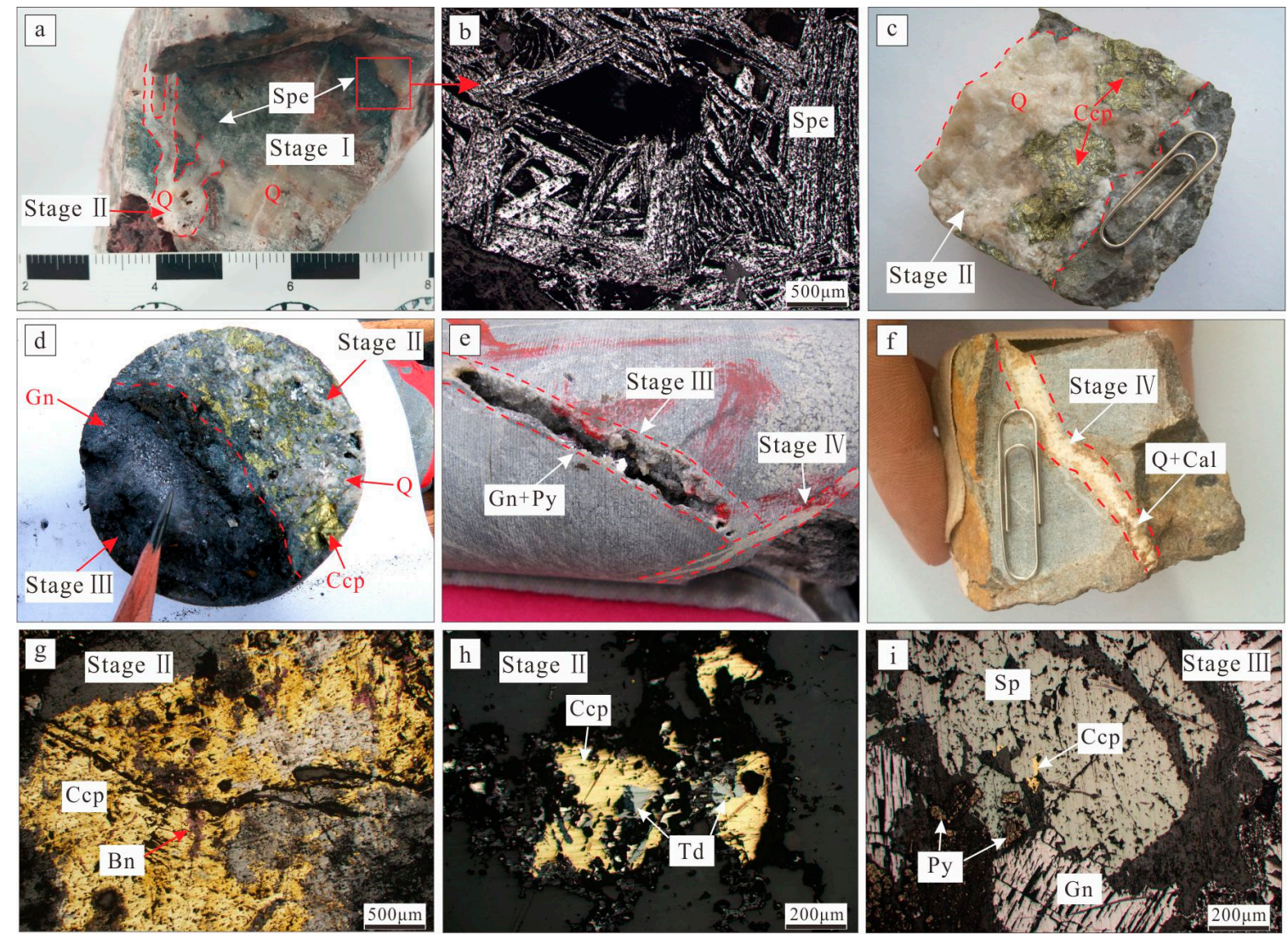

Figure 4. Photographs and photomicrographs of ore from the Chuduoqu $\mathrm{Pb}-\mathrm{Zn}-\mathrm{Cu}$ deposit. (a) Stage II quartz-chalcopyrite vein crosscutting stage I quartz-specularite vein; (b) Specularite in stage I; (c) Stage II quartz-chalcopyrite vein crosscutting wall rock; (d) Stage III galena crosscutting stage II quartz-chalcopyrite vein; (e) Stage II quartz-carbonate vein crosscutting stage III quartz-galena-pyrite vein; (f) Stage II quartz-carbonate vein crosscutting wall rock; (g) Chalcopyrite intergrown with bornite in stage II; (h) Chalcopyrite intergrown with tetrahedrite in stage II; (i) Sphalerite intergrown with galena, little chalcopyrite and pyrite in stage III. Q—quartz; Cal—Calcite; Spe—specularite; Py—pyrite; $\mathrm{Ccp}$ —chalcopyrite; $\mathrm{Sp}$-sphalerite; $\mathrm{Gn}$-galena; $\mathrm{Bn}$-bornite; $\mathrm{Td}$-tetrahedrite. 


\begin{tabular}{|c|c|c|c|c|c|}
\hline \multirow{2}{*}{ Mineral } & \multicolumn{4}{|c|}{ Hydrothermal Period } & \multirow{2}{*}{$\begin{array}{c}\text { Supergen } \\
\text { Period }\end{array}$} \\
\hline & Stage I & Stage II & Stage III & Stage IV & \\
\hline \multicolumn{6}{|c|}{ Specularite } \\
\hline Pyrite & & & & $=-$ & \\
\hline \multicolumn{6}{|l|}{ Chalcopyrite } \\
\hline Bornite & & $--=$ & & & \\
\hline \multicolumn{6}{|l|}{ Tetrahedrite } \\
\hline \multicolumn{6}{|l|}{ Sphalerite } \\
\hline \multicolumn{6}{|l|}{ Galena } \\
\hline Pearceite & & & --- & & \\
\hline \multicolumn{6}{|l|}{ Quartz } \\
\hline \multicolumn{6}{|l|}{ Barite } \\
\hline \multicolumn{6}{|l|}{ Calcite } \\
\hline \multicolumn{6}{|l|}{ Sericite } \\
\hline \multicolumn{6}{|l|}{ Chlorite } \\
\hline Epidote & & & $-=$ & & \\
\hline \multicolumn{6}{|l|}{ Cerussite } \\
\hline \multicolumn{6}{|l|}{ Malachite } \\
\hline \multicolumn{6}{|l|}{ Azurite } \\
\hline Limonite & & & & & \\
\hline
\end{tabular}

Figure 5. Mineral paragenesis for the Chuduoqu $\mathrm{Pb}-\mathrm{Zn}-\mathrm{Cu}$ deposit.

\subsection{Quartz-Carbonate Stage (Stage IV)}

This stage is characterized by quartz-calcite veins with fewer metal sulfides compared with stage III. Some fine-veined disseminated pyrite is found. Numerous calcite veins are present (Figure $4 \mathrm{f}$ ), with minor quartz veins. The mineral assemblage is calcite + quartz + pyrite.

The supergene phase involved the formation of cerussite, malachite, azurite and limonite.

\section{Samples and Analytical Methods}

\subsection{Fluid Inclusion Measurements}

The study of fluid inclusions (FIs), including petrography, micro-thermometry, and laser Raman spectra analyses, was conducted at the Key Laboratory of Geological Fluid, Jilin University, Changchun, China. A total of 27 samples from the four hydrothermal stages of mineralization were prepared as two-sided, $0.2 \mathrm{~mm}$-thick polished sections. FIs were observed under a binocular microscope, following which representative primary FIs were selected for micro-thermometric measurements. Secondary FIs, presenting locally as trails penetrating crystal boundaries, were not analyzed [36].

The petrographic and micro-thermometric studies were performed using a heating-freezing stage (THMS-600, Linkam Scientific Instruments Ltd, Epsom, UK) with a temperature range of -195 to $600^{\circ} \mathrm{C}$. The estimated precision of the measurements is $\pm 0.1^{\circ} \mathrm{C}$ for the interval from -120 to $70{ }^{\circ} \mathrm{C}$ and $\pm 2{ }^{\circ} \mathrm{C}$ for the interval $100-500^{\circ} \mathrm{C}$. International standard samples (synthetic $\mathrm{NaCl}-\mathrm{H}_{2} \mathrm{O}$ FIs) containing pure water and $25 \%$ salinity were used for calibration. The heating rate for testing was generally $0.2-5.0^{\circ} \mathrm{C} / \mathrm{min}$, although $0.5-1.0^{\circ} \mathrm{C} / \mathrm{min}$ around phase transformation points.

The compositions of individual FIs were determined using an RM-2000 laser Raman microprobe (Renishaw, New Mills, UK) with an argon ion laser and a laser source of $514 \mathrm{~nm}$. The scanning range of 
spectra was set between 100 and $4300 \mathrm{~cm}^{-1}$ with an accumulation time of $60 \mathrm{~s}$ for each scan. The laser beam width was $1 \mu \mathrm{m}$, and the spectral resolution was $0.14 \mathrm{~cm}^{-1}$.

\subsection{Ion Chromatography Analysis}

Five quartz samples were chosen for ion chromatographic analyses of grouped fluid inclusion compositions. These samples were carefully chosen quartz particles with purities of $>98 \%$ and particle sizes ranging from 0.2 to $0.5 \mathrm{~mm}$ under a binocular microscope. The liquid phase composition analyses of the FIs were conducted at the Institute of Mineral Resources, Chinese Academy of Geological Sciences, Beijing, China. The liquid phase composition analyses were performed using an ion chromatograph (HIC-SP Super; Shimadzu Corporation, Kyoto, Japan) for which the limit of detection is $\mu \mathrm{g} / \mathrm{g}$. Each sample was placed in a quartz glass tube, following which the sample was heated for $15 \mathrm{~min}$ at $500^{\circ} \mathrm{C}$. After cooling, $5 \mathrm{~mL}$ of water was added to the tube, followed by $10 \mathrm{~min}$ of ultrasonic oscillation. Finally, the liquid composition was determined using the ion chromatograph.

\subsection{Hydrogen and Oxygen Isotope Analyses}

Seven representative quartz samples were chosen for $\mathrm{H}$ and $\mathrm{O}$ isotope analysis. $\mathrm{H}$ and $\mathrm{O}$ isotopes were analyzed using a MAT253 mass spectrometer at the Analysis and Testing Research Center of Nuclear Industry, Beijing Institute of Geology, Beijing, China, referenced to Standard Mean Ocean Water (SMOW). The procedure used for the H isotope analysis was as follows. Quartz grains were crushed to a grain size of 40-60 mesh and handpicked under a binocular microscope, resulting in a purity of $>95 \%$. Water was obtained from the primary inclusions by the heating burst method [37]. Hydrogen was produced using the zinc method [38]. The $\mathrm{H}$ isotope composition was then determined using the mass spectrometer, for which the analytical precision was $\pm 1 \%$. The procedure used for the $\mathrm{O}$ isotope analysis was as follows. The selected quartz was crushed to 200 mesh and then dried. Around 10-30 mg of the crushed sample was taken and combined with $\mathrm{BrF}_{5}$ at $550{ }^{\circ} \mathrm{C}$ to produce $\mathrm{O}$ and $\mathrm{CO}_{2}$ using a carbon furnace. The $\mathrm{O}$ isotope composition was then determined using the mass spectrometer. The analytical precision is better than $2 \%$ for $\delta \mathrm{D}$ and $0.2 \%$ for $\delta^{18} \mathrm{O}$. The isotope data are reported in standard $\delta$ notion (\%o) relative to the Vienna Standard Mean Water (V-SMOW) for oxygen and hydrogen.

\subsection{Carbon and Oxygen Isotope Analyses}

Four calcite samples from quartz-calcite veins were chosen for $\mathrm{C}$ and $\mathrm{O}$ isotope analysis. The $\mathrm{C}$ and $\mathrm{O}$ isotope analyses of calcite were performed using the $100 \%$ phosphoric acid method [39] with a MAT-251EM mass spectrometer (Thermo Fisher Scientific, Waltham, MA, USA) at the Analysis and Testing Research Center of Nuclear Industry, Beijing Institute of Geology, Beijing, China. The $\mathrm{CO}_{2}$ gas produced by the reaction of phosphoric acid with the sample at $25^{\circ} \mathrm{C}$ was analyzed to yield the $\mathrm{C}$ and $\mathrm{O}$ isotopic compositions of calcite. $\delta^{13} \mathrm{C}$ was referenced to the Pee Dee Belemnite (PDB) standard, and $\delta^{18} \mathrm{O}$ was referenced to the SMOW standard. The $\delta^{18} \mathrm{O}_{\mathrm{SMOW}}$ values were calculated using the following equation [40]: $\delta^{18} \mathrm{O}_{\mathrm{SMOW}}=1.03086 \times \delta^{18} \mathrm{O}_{\mathrm{PDB}}+30.86$. The analytical precisions were $\pm 0.1 \%$ o for carbon isotopes and $\pm 0.2 \%$ for oxygen isotopes.

\subsection{Sulfur and Lead Isotope Analyses}

Fourteen sulfide samples were chosen for $S$ isotope analysis. Four sulfide samples were chosen for $\mathrm{Pb}$ isotope analysis. The $\mathrm{S}$ and $\mathrm{Pb}$ isotopes of the metal sulfides were analyzed at the Analysis and Testing Research Center of Nuclear Industry, Beijing Institute of Geology, Beijing, China. The S isotope analyses were performed using a MAT253 gas isotope mass spectrometer with an analytical precision of better than $\pm 0.2 \%$. The sulfide reference materials were the GBW-04414 and GBW-04415 Ag sulfide standards, and their determined $\delta^{34} S$ values were $-0.07 \%$ o $\pm 0.13 \%$ o and $22.15 \%$ o $\pm 0.14 \%$, respectively. The $\mathrm{Pb}$ isotopes were measured by thermal ionization mass spectrometry using an ISOPROBE-T mass spectrometer, and the analytical precision was better than $0.005 \%$ for $1 \mu \mathrm{g}$ of ${ }^{208} \mathrm{~Pb} /{ }^{206} \mathrm{~Pb}$. 


\section{Fluid Inclusion Results}

\subsection{Petrographic Characteristics}

The petrographic investigation revealed that the primary FIs of the various hydrothermal metallogenic stages are distributed mainly in groups and a few isolated examples, indicating that they were captured concurrently [36].

On the basis of phases, the degree of filling, and combination relationship of FIs at room temperature, two distinct fluid inclusion types were recognized in the studied quartz, barite, and calcite samples from the Chuduoqu $\mathrm{Pb}-\mathrm{Zn}-\mathrm{Cu}$ deposit, as follows.

Liquid-rich (L-type) FIs are the most abundant fluid inclusion type in the various mineralization stages. These inclusions consist of two phases (vapor and liquid water) at room temperature. They contain a vapor phase occupying 5-20 vol. \% of the inclusion volume. The sizes of these inclusions range from 5 to $20 \mu \mathrm{m}$, and they exhibit round, sub-rectangular, and irregular shapes (Figure 6a-c,e,g). The L-type inclusions occur in isolation or as clusters along healed crystals and homogenize to liquid during heating.

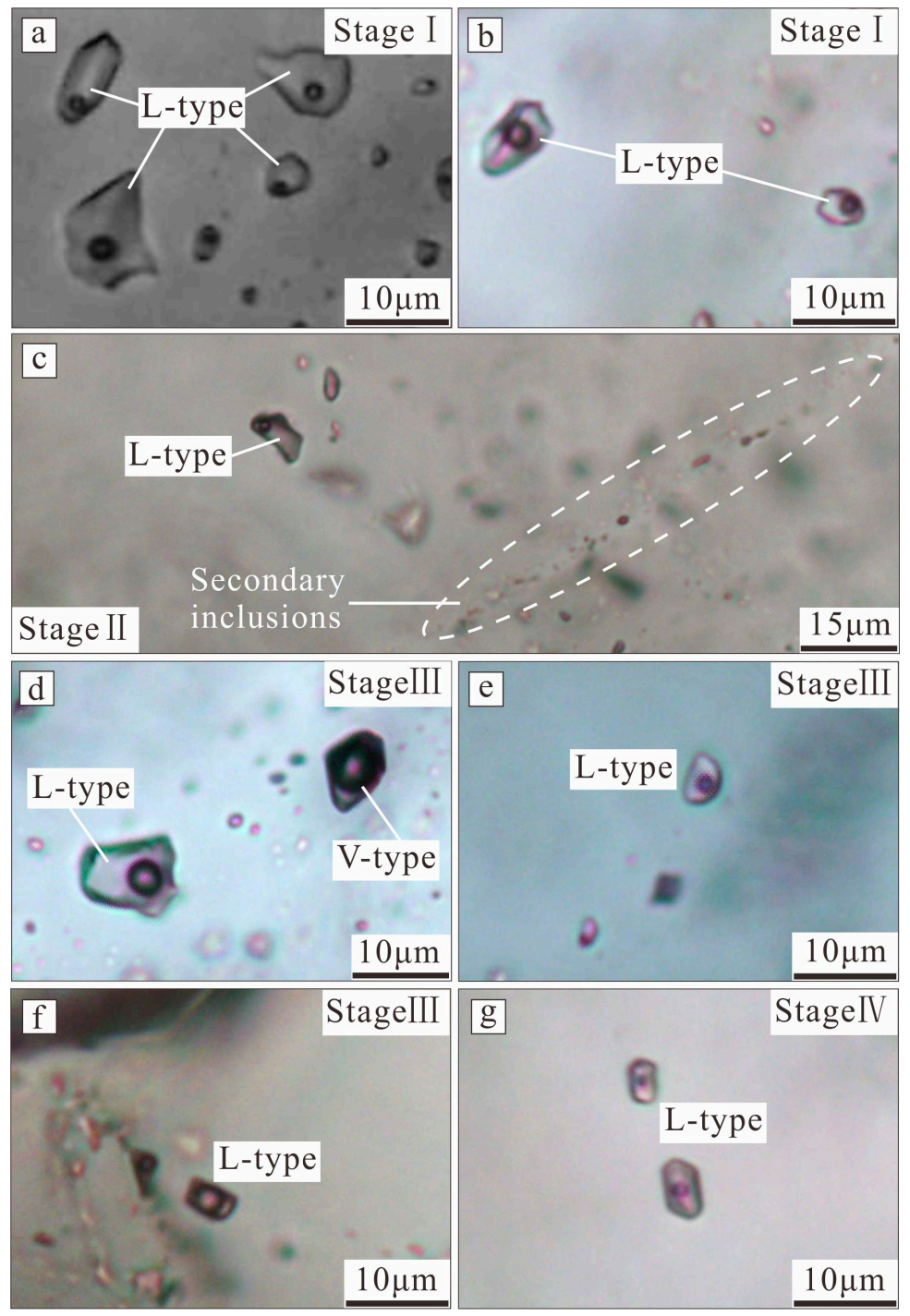

Figure 6. Photomicrographs of fluid inclusions in Stages I-IV in the Chuduoqu $\mathrm{Pb}-\mathrm{Zn}-\mathrm{Cu}$ deposit. (a) L-type inclusions in Stage I quartz; (b) L-type inclusions in Stage I quartz; (c) L-type inclusions in Stage II quartz; (d) Coexisting V-type and L-type fluid inclusions in Stage III quartz; (e) L-type inclusions in Stage III quartz; (f) V-type inclusions in Stage III quartz; (g) L-type inclusions in Stage IV quartz. 
Vapor-rich (V-type) FIs are identified in the quartz crystals of mineralization stage III. These inclusions consist of two phases (vapor and liquid water) at room temperature and $60-90$ vol. \% of the inclusion volume is occupied by vapor bubbles (Figure $6 \mathrm{~d}, \mathrm{f})$. These FIs are generally round or oval in shape and measure 5-15 $\mu \mathrm{m}$ in size. The V-type FIs occur in isolation or coexist with L-type FIs and homogenize to vapor during heating.

\subsection{Microthermometry}

On the basis of field investigations of the Chuduoqu $\mathrm{Pb}-\mathrm{Zn}$-Cu deposit, samples were collected from veins in ore bodies M8-M11. The obtained quartz, barite and calcite samples of the different mineralization stages were prepared as inclusion tablets. The microthermometric data for the FIs from the four different stages of mineralization are summarized in Table 1 and presented in Figure 7. In addition, on freezing/warming, FIs from stage II and stage III exhibit eutectic temperatures varying from $-31.5^{\circ} \mathrm{C}$ to $-29.5^{\circ} \mathrm{C}$ (Table 1), which is obviously below the eutectic temperature of $\mathrm{H}_{2} \mathrm{O}-\mathrm{NaCl}$ $\left(-21.2^{\circ} \mathrm{C}\right)$ or the $\mathrm{H}_{2} \mathrm{O}-\mathrm{NaCl}-\mathrm{KCl}\left(-22.9^{\circ} \mathrm{C}\right)$ system [41], indicating the presence of other ions besides $\mathrm{Na}^{+}$and $\mathrm{K}^{+}$(detected as $\mathrm{Mg}^{2+}$, and $\mathrm{Ca}^{2+}$ by the ion chromatography method, see Section 5.4). According to data shown by Crawford [42], in many of the chloride systems in fluid inclusions, for concentrations below $10 \mathrm{wt} . \%$, freezing point depression curves are very similar, so we assume the fluids as approximating the $\mathrm{H}_{2} \mathrm{O}-\mathrm{NaCl}$ system in our salinity estimations by using the equation of Bodnar [43].

FIs characteristics for stage I quartz are based on data for L-type inclusions. All the L-type FIs have homogenization temperatures of 318 to $370{ }^{\circ} \mathrm{C}$, final ice-melting temperatures of -8.1 to $-5.6{ }^{\circ} \mathrm{C}$, and calculated salinities of 8.68 to $11.81 \mathrm{wt} . \% \mathrm{NaCl}$ equivalent (Figure $7 \mathrm{a}, \mathrm{b}$ ). Initial ice melting temperatures on freezing/warming were not confidently obtained.

FIs characteristics for stage II quartz and barite are based on data for L-type FIs. These L-type FIs have homogenization temperatures of 250 to $308{ }^{\circ} \mathrm{C}$ for quartz and 250 to $287^{\circ} \mathrm{C}$ for barite. The final ice-melting temperatures range from -7.8 to $-4.8^{\circ} \mathrm{C}$ and from -7.2 to $-3.3^{\circ} \mathrm{C}$, respectively. The calculated salinities for FIs in quartz and barite range from 7.59 to $11.46 \mathrm{wt} . \%$ and from 5.41 to $10.73 \mathrm{wt} . \% \mathrm{NaCl}$ equivalent (Figure 7c,d), respectively. On freezing/warming, FIs exhibit eutectic temperatures of $-29.5 \pm 0.5^{\circ} \mathrm{C}$ for quartz and $-31.2 \pm 0.5{ }^{\circ} \mathrm{C}$ for barite, respectively, suggesting the presence of $\mathrm{NaCl}$, as well as $\mathrm{Mg}$ and Ca chlorides in solution [42].

FIs characteristics for stage III quartz are based on data for L-type and V-type FIs. The L-type FIs have homogenization temperatures of 231 to $294^{\circ} \mathrm{C}$, final ice-melting temperatures of -6.5 to $-2.9^{\circ} \mathrm{C}$, and calculated salinities of 4.80 to $9.86 \mathrm{wt} . \% \mathrm{NaCl}$ equivalent (Figure $7 \mathrm{e}, \mathrm{f}$ ). The V-type FIs have homogenization temperatures of 230 to $259^{\circ} \mathrm{C}$, final ice-melting temperatures of -5.7 to $-2.7^{\circ} \mathrm{C}$, and calculated salinities of 4.49 to $8.81 \mathrm{wt} . \% \mathrm{NaCl}$ equivalent. On freezing/warming, L-type FIs from stage III exhibit eutectic first melting temperatures of $-31.5 \pm 0.5^{\circ} \mathrm{C}$, indicating the presence of $\mathrm{NaCl}$, as well as $\mathrm{Mg}$ and Ca chlorides in solution [42]. For V-type FIs, their liquid phase is too small to observe the eutectic temperature.

Table 1. Microthermometric data and relative parameters of fluid inclusions.

\begin{tabular}{cccccccc}
\hline $\begin{array}{c}\text { Mineralized } \\
\text { Stages }\end{array}$ & $\begin{array}{c}\text { Host } \\
\text { Minerals }\end{array}$ & $\begin{array}{c}\text { Inclusion } \\
\text { Type }\end{array}$ & No. & $\begin{array}{c}\text { Tm-eu } \\
\left({ }^{\circ} \mathbf{C}\right)\end{array}$ & Tm-ice $\left({ }^{\circ} \mathbf{C}\right)$ & Th $\left({ }^{\circ} \mathbf{C}\right)$ & $\begin{array}{c}\text { Salinity (NaCl } \\
\text { wt.\%) }\end{array}$ \\
\hline I & Quartz & L-type & 28 & & from -8.1 to -5.6 & $318-370$ & $8.68-11.81$ \\
II & Quartz & L-type & 33 & $-29.5 \pm 0.5$ & from -7.8 to -4.8 & $250-308$ & $7.59-11.46$ \\
II & Barite & L-type & 18 & $-31.2 \pm 0.5$ & from -7.2 to -3.3 & $250-287$ & $5.41-10.73$ \\
III & Quartz & L-type & 45 & $-31.5 \pm 0.5$ & from -6.5 to -2.9 & $231-294$ & $4.80-9.86$ \\
III & Quartz & V-type & 11 & & from -5.7 to -2.7 & $230-259$ & $4.49-8.81$ \\
IV & Quartz & L-type & 23 & & from -4.4 to -2.6 & $162-233$ & $4.34-7.02$ \\
IV & Calcite & L-type & 28 & & from -3.1 to -1.2 & $144-219$ & $2.07-5.10$ \\
\hline
\end{tabular}

Tm-eu $\left({ }^{\circ} \mathrm{C}\right)$ - eutectic temperature (first ice melting temperature); Tm-ice $\left({ }^{\circ} \mathrm{C}\right)$-final ice melting temperature. 

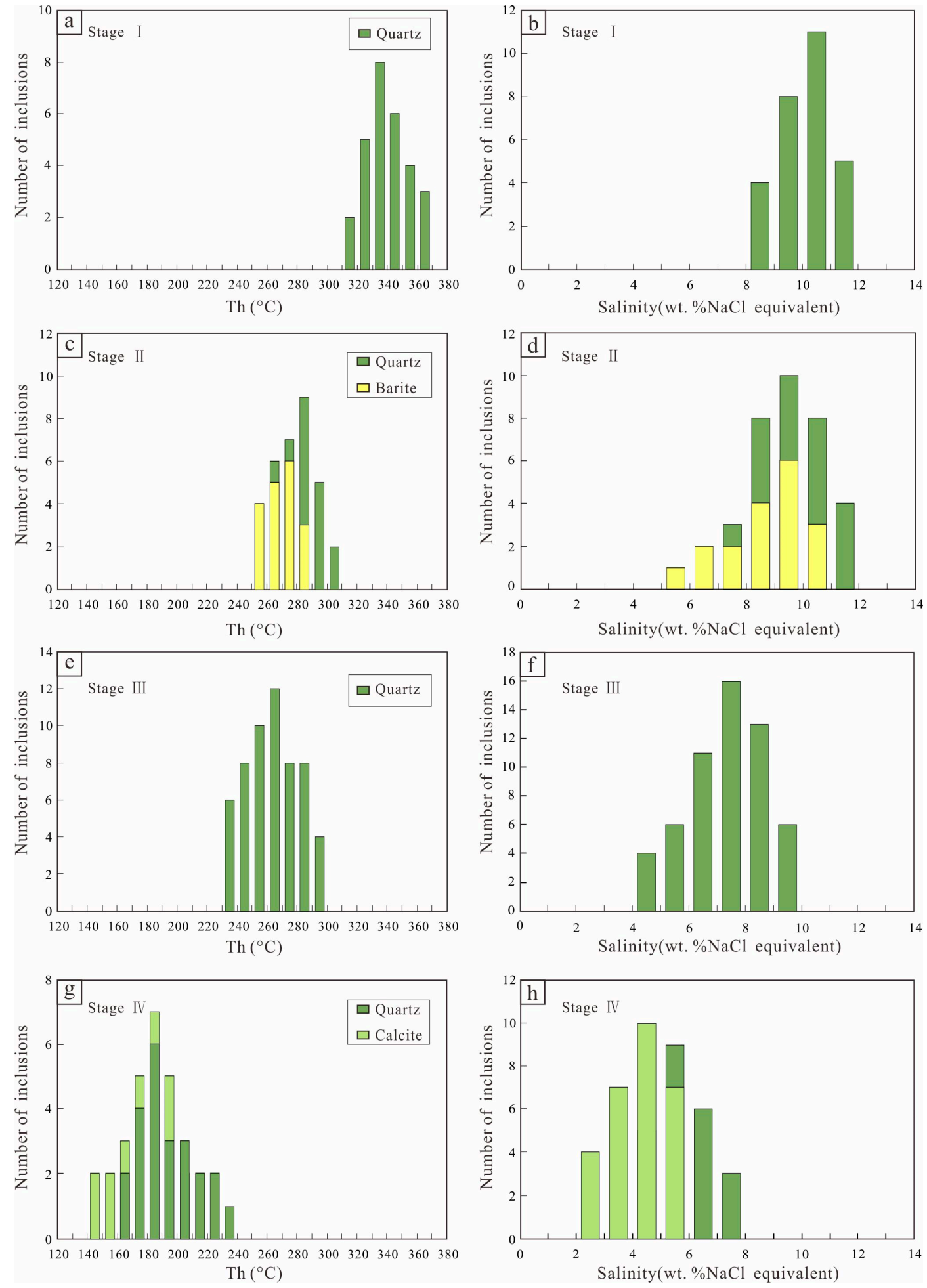

Figure 7. Histograms of homogenization temperatures and salinities of fluid inclusions from the different stages of the Chuduoqu $\mathrm{Pb}-\mathrm{Zn}$-Cu deposit. (a) Homogenization temperatures for L-type, Stage I quartz; (b) Salinity for L-type, Stage I quartz; (c) Homogenization temperatures for L-type, Stage II quartz and barite; (d) Salinity for L-type, Stage II quartz and barite; (e) Homogenization temperatures for L-type and V-type, Stage III quartz; (f) Salinity for L-type and V-type, Stage III quartz; (g) Homogenization temperatures for L-type, Stage IV quartz and calcite; (h) Salinity for L-type, Stage IV quartz and calcite. 
FIs characteristics for stage IV quartz and calcite are based on data for L-type FIs. The L-type FIs in quartz and calcite have homogenization temperatures of 162 to $233^{\circ} \mathrm{C}$ and 144 to $219{ }^{\circ} \mathrm{C}$, and final ice-melting temperatures of -4.4 to $-2.6^{\circ} \mathrm{C}$ and -3.1 to $-1.2{ }^{\circ} \mathrm{C}$, respectively. The calculated salinities for FIs in quartz and calcite range from 4.34 to $7.02 \mathrm{wt} . \%$ and from 2.07 to $5.10 \mathrm{wt} . \% \mathrm{NaCl}$ equivalent (Figure $7 \mathrm{~g}, \mathrm{~h}$ ), respectively. Initial ice melting temperatures on freezing/warming were not confidently obtained.

The microthermometry results show that the FIs are medium temperature and medium to low salinity.

\subsection{Laser Raman Spectroscopy}

Representative FIs from the Chuduoqu $\mathrm{Pb}-\mathrm{Zn}$ - $\mathrm{Cu}$ deposit were studied using laser Raman spectroscopy to determine their gas compositions. The results suggest that the vapor phases of the L-type FIs, either coexisting with the V-type FIs or as individual assemblages, are dominated by $\mathrm{H}_{2} \mathrm{O}$, with trace amount of $\mathrm{CO}_{2}$ and $\mathrm{N}_{2}$ (Figure 8a). Trace amount of $\mathrm{CO}_{2}$ and $\mathrm{N}_{2}$ are also found in the vapor phases of the V-type FIs in the Quartz-polymetallic sulfide stage (Figure 8b). In summary, the FIs can be described as the $\mathrm{H}_{2} \mathrm{O}-\mathrm{NaCl} \pm \mathrm{CO}_{2} \pm \mathrm{N}_{2}$ system.
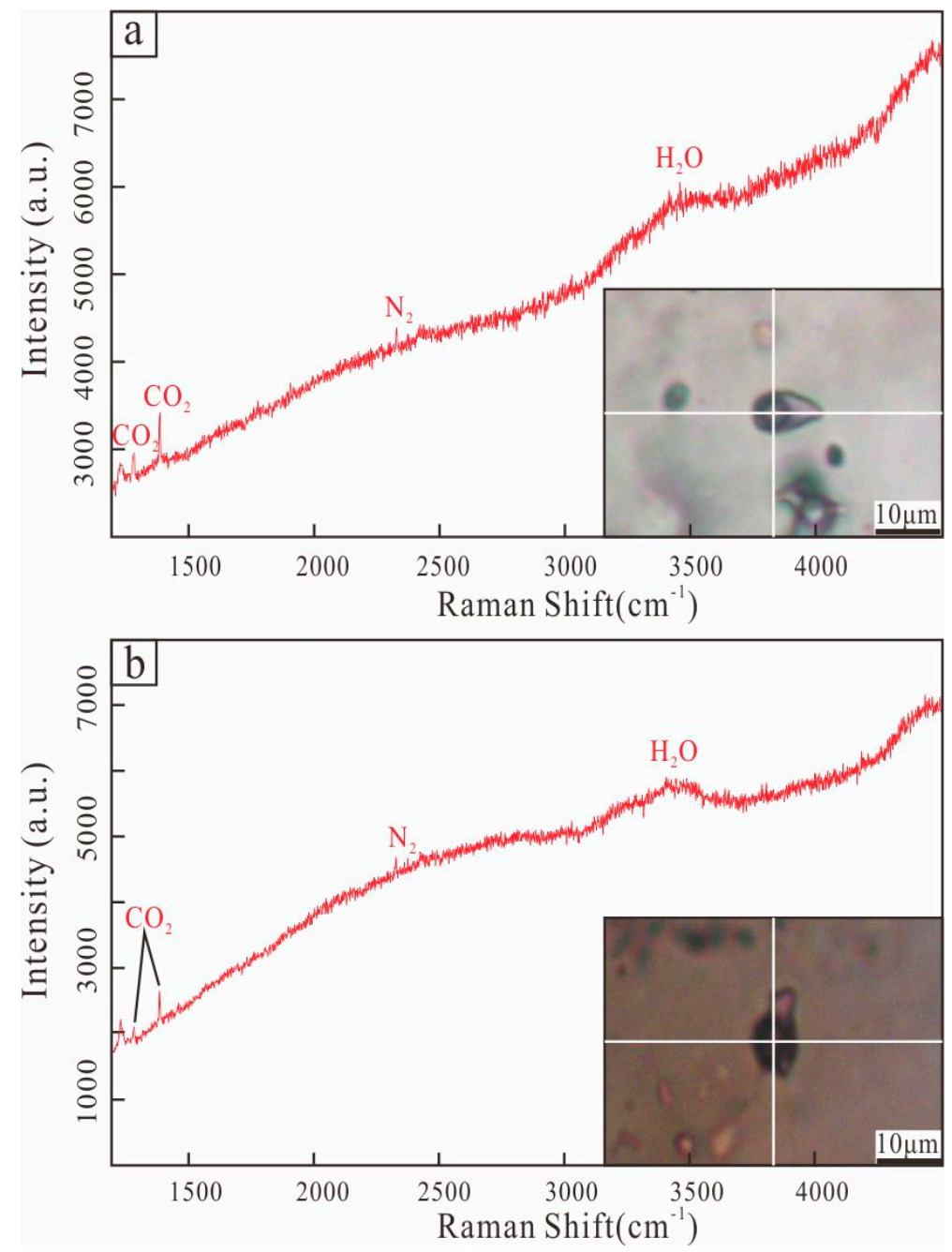

Figure 8. Representative laser Raman spectra for fluid inclusions from the Chuduoqu $\mathrm{Pb}-\mathrm{Zn}-\mathrm{Cu}$ deposit. (a) $\mathrm{H}_{2} \mathrm{O}, \mathrm{N}_{2}$ and $\mathrm{CO}_{2}$ spectra of the vapor phase in L-type inclusion; (b) $\mathrm{H}_{2} \mathrm{O}, \mathrm{N}_{2}$ and $\mathrm{CO}_{2}$ spectra of the vapor phase in $\mathrm{V}$-type inclusion. 


\subsection{Ion Chromatography}

The results obtained by the ion chromatography method are affected by the presence of secondary inclusions and must be taken with caution. The samples for ion chromatography were obtained from the chalcopyrite-bearing quartz veins of stage II in ore bodies M8 and M9. The cations in the liquid of the FIs were mainly $\mathrm{Ca}^{2+}$ and $\mathrm{Mg}^{2+}$ with lesser $\mathrm{K}^{+}$and $\mathrm{Na}^{+}$. The anions were mainly $\mathrm{Cl}^{-}$and $\mathrm{SO}_{4}{ }^{2-}$ with lesser $\mathrm{F}^{-}, \mathrm{NO}^{2-}$, and $\mathrm{NO}^{3-}$ (Table 2).

Table 2. The results of the ion chromatography analysis of the fluid inclusions exist in quartz from the Chuduoqu $\mathrm{Pb}-\mathrm{Zn}-\mathrm{Cu}$ deposit.

\begin{tabular}{cccccc}
\hline Sample No. & CDQ-TC72-B & CDQ-TC72-B & CDQ-TC72-B & CDQ-P1-26 & \multicolumn{2}{c}{ CDQ-LX1-25 } \\
\hline Mineral & Quartz & Quartz & Quartz & Quartz & Quartz \\
\hline Sample Location & M8 Orebody & M8 Orebody & M8 Orebody & M9 Orebody & M9 Orebody \\
\hline Mineralization Stages & II & II & II & II & II \\
\hline \multicolumn{7}{r}{ Major Ion Components $(\mu \mathrm{g} / \mathbf{g})$} \\
\hline $\mathrm{Na}^{+}$ & 1.4 & 2.92 & 3.53 & 2.7 & 3.07 \\
$\mathrm{~K}^{+}$ & 3.49 & 1.61 & 2.61 & 1.57 & 3.69 \\
$\mathrm{Mg}^{2+}$ & 1.46 & 1.15 & 4.15 & 2.85 & 8.09 \\
$\mathrm{Ca}^{2+}$ & 8.2 & 4.96 & 17.89 & 16.93 & 48.92 \\
$\mathrm{~F}^{-}$ & 0.22 & 0.04 & 0.12 & 0.05 & 0.33 \\
$\mathrm{Cl}^{-}$ & 5.53 & 8.49 & 10.64 & 2.73 & 4.23 \\
$\mathrm{NO}^{2-}$ & 0.36 & 0.59 & 0.6 & 0.73 & 0.77 \\
$\mathrm{NO}^{3-}$ & 0.51 & 0.66 & 1.17 & 0.22 & 0.79 \\
$\mathrm{SO}_{4}{ }^{2-}$ & 13.41 & 9.91 & 55.12 & 5.53 & 20.32 \\
\hline
\end{tabular}

\section{Isotopes Systematics}

\subsection{Oxygen and Hydrogen Isotopes}

Seven quartz samples of ore-forming stages I, II and III obtained from ore bodies M5, M8, and M9 were selected for $\mathrm{H}-\mathrm{O}$ isotope analysis. The results of the analysis are reported in Table 3 . The $\delta^{18} \mathrm{O}_{\mathrm{V}-\mathrm{SMOW}}$ values range from $9.5 \%$ o to $15.3 \%$, the $\delta^{18} \mathrm{O}_{\mathrm{H} 2 \mathrm{O}}$ values from $-0.4 \%$ o to $9.1 \%$, and $\delta \mathrm{D}_{\mathrm{V}-\mathrm{SMOW}}$ values from $-113.2 \%$ o to $-93.8 \%$ o.

Table 3. The hydrogen and oxygen isotope compositions of the fluid inclusion of stage I, II and III of the Chuduoqu $\mathrm{Pb}-\mathrm{Zn}$-Cu deposit.

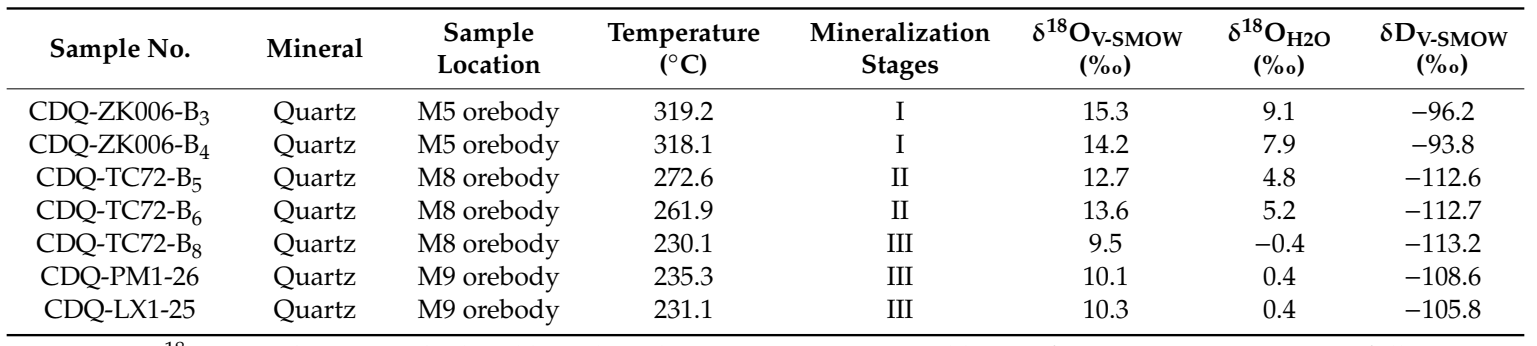

Note: $\delta^{18} \mathrm{O}_{\mathrm{H} 2 \mathrm{O}}$ values are calculated based on the oxygen isotope equilibrium fractionation equation as follows: $\delta^{18} \mathrm{O}_{\text {V-SMOW }}-\delta^{18} \mathrm{O}_{\mathrm{H} 2 \mathrm{O}}=1000 \ln \alpha_{\text {quartz-water }}=3.38 \times 10^{6} / T^{2}-3.40$ [44], Temperatures used in the calculations are derived from fluid inclusion microthermometric data.

\subsection{Carbon and Oxygen Isotopes}

The C-O isotopic compositions of the carbonate samples from ore bodies M1, M9, M10, and M11 of the ore-forming stage IV, together with previously published data, are listed in Table 4 . The $\delta^{13} \mathrm{C}_{\mathrm{PDB}}$ values range from $-7.5 \%$ o to $-5.4 \%$, and $\delta^{18} \mathrm{O}_{\mathrm{SMOW}}$ values from $9.9 \%$ o to $12.1 \%$. 
Table 4. The $\mathrm{C}-\mathrm{O}$ isotopic compositions of the Chuduoqu $\mathrm{Pb}-\mathrm{Zn}-\mathrm{Cu}$ deposit.

\begin{tabular}{|c|c|c|c|c|c|c|c|}
\hline Sample No. & Mineral & $\begin{array}{c}\text { Sample } \\
\text { Location }\end{array}$ & $\begin{array}{c}\text { Mineralization } \\
\text { Stages }\end{array}$ & $\begin{array}{c}\delta^{13} C_{P D B} \\
(\%)\end{array}$ & $\begin{array}{c}\delta^{18} \mathrm{O}_{\mathrm{PDB}} \\
(\% \mathrm{oo})\end{array}$ & $\begin{array}{c}\delta^{18} \mathrm{O}_{\text {SMOW }} \\
(\% \text { oo })\end{array}$ & Reference \\
\hline CDQ-PM1-B & Calcite & M11 orebody & IV & -5.4 & -19.3 & 11.0 & This study \\
\hline CDQ-ZK3205-B 10 & Calcite & M9 orebody & IV & -7.5 & -20.3 & 9.9 & This study \\
\hline CDQ-SZK802-B & Calcite & M10 orebody & IV & -6.3 & -18.5 & 11.8 & This study \\
\hline CDQ-LX3-W 8 & Calcite & M1 orebody & IV & -6.5 & -18.3 & 12.0 & This study \\
\hline CDQ-ZK006-C 20 & Calcite & M5 orebody & IV & -5.6 & -19.2 & 11.1 & [13] \\
\hline CDQ-ZK006-W 14 & Calcite & M5 orebody & IV & -6.2 & -18.2 & 12.1 & [13] \\
\hline CDQ-ZK006-W 25 & Calcite & M5 orebody & IV & -6.3 & -18.7 & 11.6 & [13] \\
\hline CDQ-ZK006-W 26 & Calcite & M5 orebody & IV & -7.5 & -19.7 & 10.6 & [13] \\
\hline
\end{tabular}

Notes: $\delta^{18} \mathrm{O}_{\mathrm{SMOW}}=1.03086 \times \delta^{18} \mathrm{O}_{\mathrm{V}-\mathrm{PDB}}+30.86[40]$.

\subsection{Sulfur Isotopes}

Sulfur isotopic compositions were determined for fourteen sulfide samples from ore bodies M9, M10, and M11 of the Chuduoqu deposit (Table 5). The $\delta^{34} \mathrm{~S}_{\mathrm{CDT}}$ values of the sulfide range from $-3.8 \%$ to $2.9 \%$ with a mean value of $-0.5 \%$.

Table 5. Sulfur isotopic compositions of the Chuduoqu $\mathrm{Pb}-\mathrm{Zn}-\mathrm{Cu}$ deposit.

\begin{tabular}{|c|c|c|c|c|}
\hline Sample No. & Mineral & Sample Location & Mineralization Stages & $\delta^{34} S_{\mathrm{CDT}}(\%)$ \\
\hline CDQ-P1-B 1 & Chalcopyrite & M11 orebody & II & 1.2 \\
\hline CDQ-SZK802-B 2 & Chalcopyrite & M10 orebody & II & 0.4 \\
\hline CDQ-ZK3205-B & Chalcopyrite & M9 orebody & II & 2.9 \\
\hline CDQ-ZK3205-B 6 & Chalcopyrite & M9 orebody & II & 2.8 \\
\hline CDQ-ZK3205-B 7 & Chalcopyrite & M9 orebody & II & 2.5 \\
\hline CDQ-ZK3205-B 8 & Galena & M9 orebody & III & -0.3 \\
\hline CDQ-ZK3205-B9 & Galena & M9 orebody & III & -1.7 \\
\hline CDQ-ZK3205-B 10 & Galena & M9 orebody & III & -2.6 \\
\hline CDQ-TC29-B 13 & Galena & M9 orebody & III & -3.8 \\
\hline CDQ-ZK3205-B 11 & Galena & M9 orebody & III & -2.3 \\
\hline CDQ-ZK3205-B 12 & Galena & M9 orebody & III & -2.1 \\
\hline CDQ-ZK3205-B 13 & Sphalerite & M9 orebody & III & -1.6 \\
\hline CDQ-ZK3205-B & Sphalerite & M9 orebody & III & -1.4 \\
\hline CDQ-ZK3205-B 15 & Sphalerite & M9 orebody & III & -1.2 \\
\hline
\end{tabular}

\subsection{Lead Isotopes}

Lead isotopic compositions of the sulfide samples from ore body M9, together with previously published data, are listed in Table 6 . The ${ }^{206} \mathrm{~Pb} /{ }^{204} \mathrm{~Pb}$ ratios of these sulfides range from 18.652 to 18.773 , the ${ }^{207} \mathrm{~Pb} /{ }^{204} \mathrm{~Pb}$ ratios from 15.651 to 15.694 , and ${ }^{208} \mathrm{~Pb} /{ }^{204} \mathrm{~Pb}$ ratios from 38.803 to 39.014 .

Table 6. Lead compositions of the Chuduoqu $\mathrm{Pb}-\mathrm{Zn}-\mathrm{Cu}$ deposit.






\section{Discussion}

\subsection{Origin and Evolution of the Ore-Forming Fluids}

The $\mathrm{O}$ and $\mathrm{H}$ isotopic compositions of selected minerals at different mineralization stages are widely used in the study of the source and evolution process of the hydrothermal fluids [45]. In the $\delta^{18} \mathrm{O}_{\mathrm{H} 2 \mathrm{O}}-\delta^{18} \mathrm{D}_{\mathrm{H} 2 \mathrm{O}}$ diagram (Figure 9), the $\delta^{18} \mathrm{O}_{\mathrm{H} 2 \mathrm{O}}$ values decrease from stage I to stage III, the $\delta^{18} \mathrm{O}_{\mathrm{H} 2 \mathrm{O}}-\delta^{18} \mathrm{D}_{\mathrm{H} 2 \mathrm{O}}$ data from stage I plot close to the field of magmatic water (Figure 9), indicating that the magmatic fluid may play an important role in the development of ore-forming fluid. However, compared with typical magmatic water, the $\delta^{18} \mathrm{D}_{\mathrm{H} 2 \mathrm{O}}$ values of the fluids we sampled are significantly lower than those for magmatic water (from $-50 \%$ o to $-85 \%$ o) (Figure $9,[46]$ ).

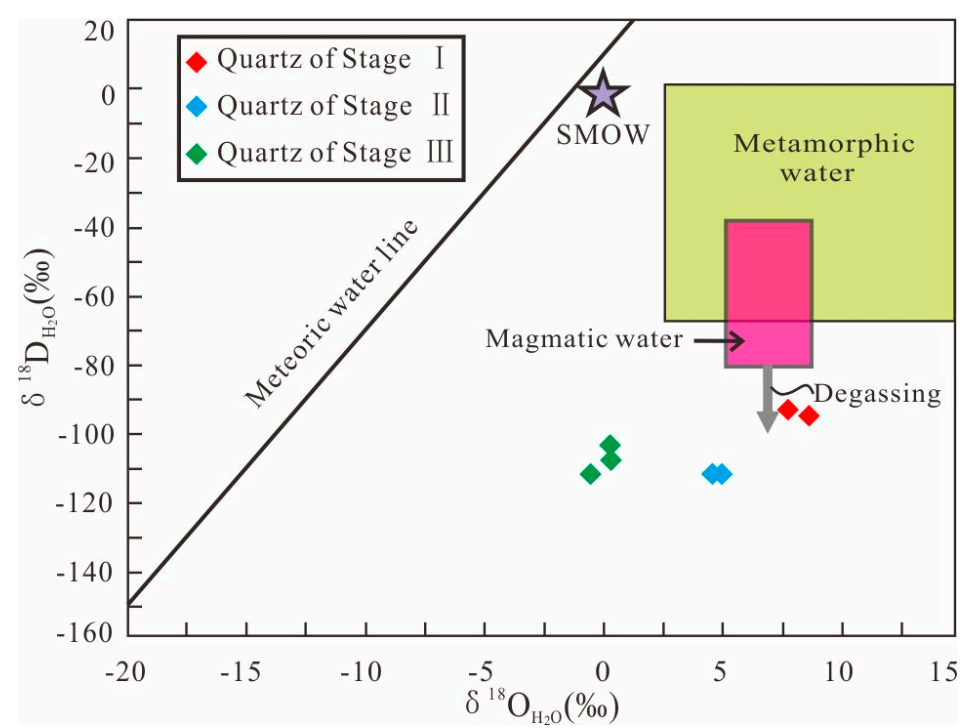

Figure 9. The $\delta^{18} \mathrm{O}_{\mathrm{H} 2 \mathrm{O}}-\delta^{18} \mathrm{D}_{\mathrm{H} 2 \mathrm{O}}$ diagram of the ore-forming fluid of the Chuduoqu Pb-Zn-Cu deposit (after [45]).

Previous studies $[47,48]$ have suggested that a continuous degassing of parent magma in an open system would decrease the $\delta^{18} \mathrm{D}_{\mathrm{H} 2 \mathrm{O}}$ values in the residual water during the late crystallization phase, whereas the influence on the $\delta^{18} \mathrm{O}_{\mathrm{H} 2 \mathrm{O}}$ value would be less. We attribute this isotope change in the Chuduoqu $\mathrm{Pb}-\mathrm{Zn}-\mathrm{Cu}$ deposit to the continuous degassing of the parent magma in an open system. However, although we attempted to heat treat the sample to remove secondary inclusions prior to isotope analysis, it does not preclude the possibility that the low $\delta^{18} \mathrm{D}_{\mathrm{H} 2 \mathrm{O}}$ value from stage I is affected by secondary fluid inclusions.

The $\delta^{18} \mathrm{O}_{\mathrm{H} 2 \mathrm{O}}-\delta^{18} \mathrm{D}_{\mathrm{H} 2 \mathrm{O}}$ data from stage II and stage III are lower than the data from stage I (Figure 9). In practice, however, magmatic bodies emplaced at shallow levels in the earth's crust may directly or indirectly interact with meteoric water [47]. Since the small amounts of $\mathrm{H}_{2} \mathrm{O}$ present in host magma, it should be easier for such processes to change the $\delta^{18} \mathrm{D}_{\mathrm{H} 2 \mathrm{O}}$ values of magma than the $\delta^{18} \mathrm{O}_{\mathrm{H} 2 \mathrm{O}}$ values [46]. Therefore, mixing between magmatic water and meteoric water may be a more plausible explanation for the low $\delta^{18} \mathrm{D}_{\mathrm{H} 2 \mathrm{O}}$ values from stage II to stage III in the Chuduoqu $\mathrm{Pb}-\mathrm{Zn}-\mathrm{Cu}$ deposit. Furthermore, in the homogeneous temperature-salinity diagram (Figure 10), the salinity of the fluids decreases with drop of temperature, the data also suggest the occurrence of a fluid mixing.

The differences in the $\delta^{13} C_{P D B}$ values of various carbon pools mean that $C$ isotope analysis is an important method for tracing the origin of ore-forming fluids. The $\delta^{13} \mathrm{C}_{\mathrm{PDB}}$ and $\delta^{18} \mathrm{O}_{\text {SMOW }}$ values of the eight calcite vein samples of the hydrothermal ore-forming phase of the Chuduoqu deposit range from $-7.5 \%$ o to $-5.4 \%$ ond from $9.9 \%$ o to $12.1 \%$, respectively. This range of $\delta^{13} C_{\mathrm{PDB}}$ values lies within the established range of carbon isotope values for mantle or magmatic sources (from $-9.0 \%$ to $-3 \%$, [50]. In the $\delta^{13} \mathrm{C}_{\mathrm{PDB}}-\delta^{18} \mathrm{O}_{\mathrm{SMOW}}$ diagram (Figure 11), the $\mathrm{C}-\mathrm{O}$ isotope composition data for the 
calcite vein samples of mineralization stage IV fall in or around the granite field and parallel with the direction of low temperature alteration of granite, which shows that substantial volumes of magmatic water were still involved in the ore-forming process during late-stage mineralization.

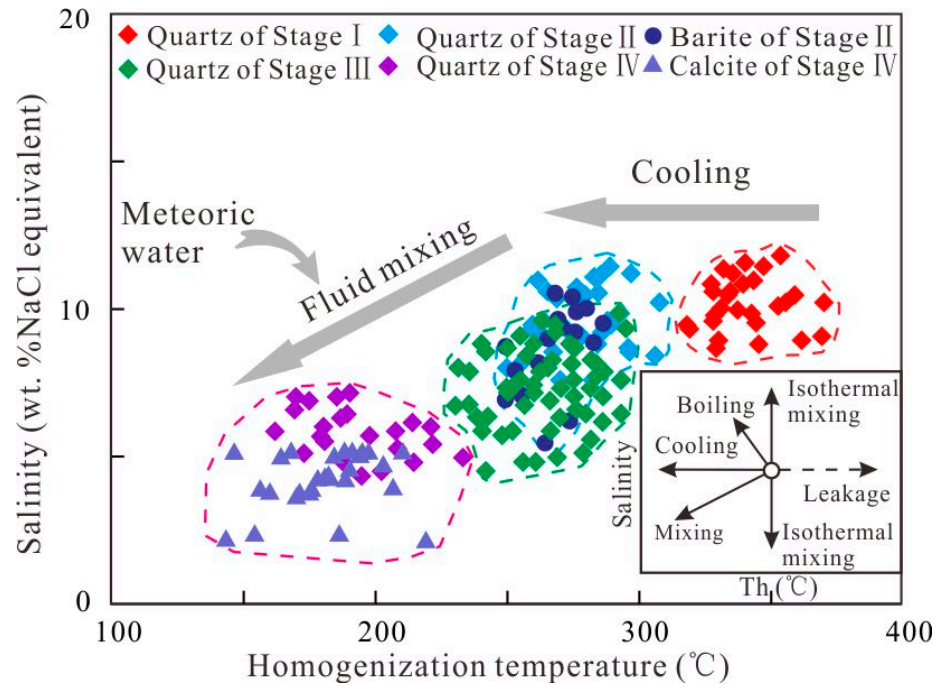

Figure 10. Homogenization temperature vs. salinity diagram showing the evolution of the ore-forming fluids for different groups of the fluid inclusions in the Chuduoqu $\mathrm{Pb}-\mathrm{Zn}-\mathrm{Cu}$ deposit. Inset illustration for different fluid evolution paths is based on Shepherd et al. [49].

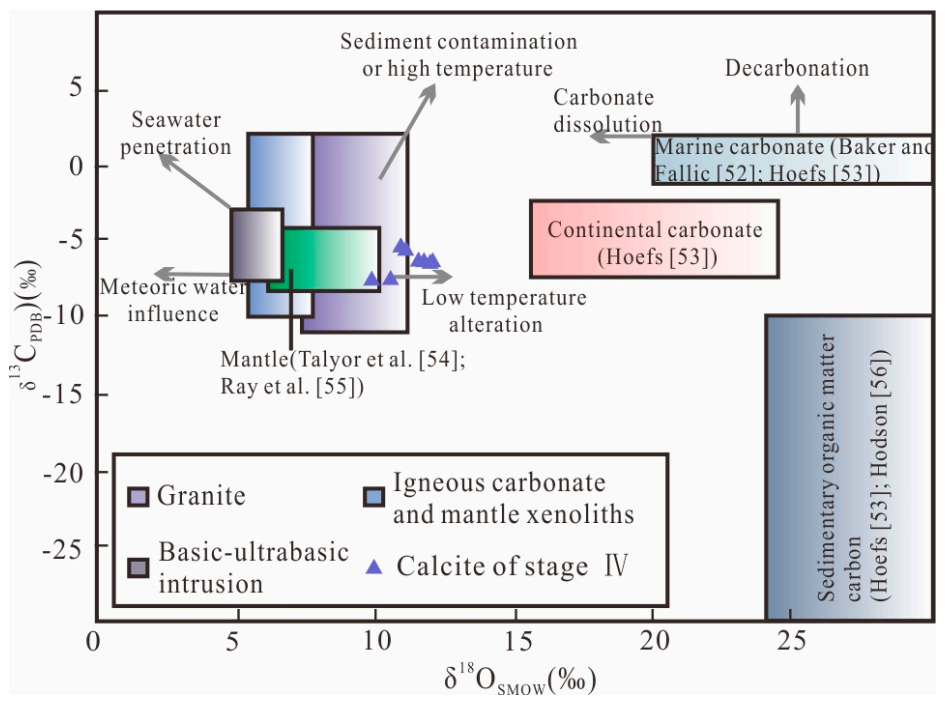

Figure 11. The $\delta^{13} \mathrm{C}_{\mathrm{PDB}}-\delta^{18} \mathrm{O}_{\mathrm{SMOW}}$ diagram of the Chuduoqu $\mathrm{Pb}-\mathrm{Zn}-\mathrm{Cu}$ deposit (base map modified after Demény et al. [51]. The data of mantle, continental carbonate, marine carbonate and sedimentary organic matter carbon are from [52-56]. This plot offers information about the various processes of $\mathrm{CO}_{2}$ and carbonate ions including meteoric water influence, sea water penetration, sediment contamination and high temperature influence, low temperature alteration [57-59], decarbonate and carbonate dissolution [60].

FI components also provide information on the sources of ore-forming fluids. The $\mathrm{Ca}^{2+}$ content in the fluids of mineralization stage II samples has a range of 4.96-48.92 $\mu \mathrm{g} / \mathrm{g}$ with a mean of $19.38 \mu \mathrm{g} / \mathrm{g}$, the $\mathrm{Mg}^{2+}$ content has a range of $1.15-8.09 \mu \mathrm{g} / \mathrm{g}$ with a mean of $3.54 \mu \mathrm{g} / \mathrm{g}$, the $\mathrm{Na}^{+}$content has a range of $1.40-3.53 \mu \mathrm{g} / \mathrm{g}$ with a mean of $2.72 \mu \mathrm{g} / \mathrm{g}$, and the $\mathrm{K}^{+}$content has a range of $1.57-3.69 \mu \mathrm{g} / \mathrm{g}$ with a mean of $2.59 \mu \mathrm{g} / \mathrm{g}$. 
Calcium in the ore-forming fluid has two possible sources: One is through the mixing with a Ca-rich fluid end member and the other is through water-rock reaction [61], namely interaction between ore-forming fluid and carbonate wall rock, which can remobilize $\mathrm{Ca}^{2+}$ from carbonate wall rock into ore-forming fluid. However, the stable isotopic compositions show that the involved external fluid end member is meteoric water, which is characterized by low-temperature, low-salinity and free of Ca. The possibility of mixing with a Ca-rich fluid can therefore be ruled out. In the hydrothermal system of Chuduoqu $\mathrm{Pb}-\mathrm{Zn}$-Cu deposit, water-rock reaction significantly dissolved the carbonate wall rock, remobilizing Ca ion into ore-forming fluid. In the same way, $\mathrm{Mg}^{2+}$ in the ore-forming fluid is also interpreted as a result of water-rock reaction.

The $\mathrm{Cl}^{-}$content of the fluids of stage II samples ranges from $2.73 \mu \mathrm{g} / \mathrm{g}$ to $10.64 \mu \mathrm{g} / \mathrm{g}$ with a mean of $6.32 \mu \mathrm{g} / \mathrm{g}$, the $\mathrm{SO}_{4}{ }^{2-}$ content ranges from $5.53 \mu \mathrm{g} / \mathrm{g}$ to $55.12 \mu \mathrm{g} / \mathrm{g}$ with a mean of $20.86 \mu \mathrm{g} / \mathrm{g}$, and the $\mathrm{F}^{-}$content ranges from $0.04 \mu \mathrm{g} / \mathrm{g}$ to $0.33 \mu \mathrm{g} / \mathrm{g}$ with a mean of $0.15 \mu \mathrm{g} / \mathrm{g}$. In summary, $\mathrm{SO}_{4}{ }^{2-}>\mathrm{Cl}^{-}>\mathrm{F}^{-}$, meaning that the fluids of stage II were S-rich aqueous solutions. The fluids with a high $\mathrm{S}$ content provided an essential source of $S$ for metal precipitation as sulfides.

The physical and chemical properties of the fluids in different mineralization stages are related to the complexity of the fluid source and evolution. Based on the $\mathrm{H}-\mathrm{O}$ isotopic data, the $\mathrm{C}-\mathrm{O}$ isotopic data and the fluid inclusion characteristics, the ore-forming fluids from stage I for the Chuduoqu $\mathrm{Pb}-\mathrm{Zn}-\mathrm{Cu}$ deposit were initially derived from magmatic water. In addition, from stage I to stage II, the homogenization temperatures of FIs show a decreasing trend, whereas the salinities are very similar, indicating a simple cooling process during the evolution of the ore-forming fluids (Figure 10, [49]). Commonly, evidence for fluid boiling could be provided by the coexistence of liquid-rich and vapor-rich fluid inclusion assemblages in the same growth zone or healed fractures [62,63]. Liquid-rich (L-type) and vapor-rich (V-type) fluid inclusions with contrast salinities (Table 1) coexist in the same petrographic assemblages in stage III (Figure 6d), indicating fluid boiling may take place in stage III. The ore-forming fluids from stage IV with characteristics of low temperature $\left(144-233^{\circ} \mathrm{C}\right)$ and salinity $(2.07-7.02 \mathrm{wt} . \%$ $\mathrm{NaCl}$ equivalent) is closely associated with addition of large volumes of meteoric waters.

In summary, the ore-forming fluids in the Chuduoqu $\mathrm{Pb}-\mathrm{Zn}-\mathrm{Cu}$ deposit is characterized by medium to low temperature $\left(144-370{ }^{\circ} \mathrm{C}\right)$, medium to low salinity $(2.07-11.81 \mathrm{wt} . \% \mathrm{NaCl}$ equivalent), and contains minor vapor component of $\mathrm{CO}_{2}$ and $\mathrm{N}_{2}$. The ore-forming fluids were mixed with a growing amount of meteoric water from stage II to stage IV, resulting in the decrease of fluid temperatures (evolved from $250{ }^{\circ} \mathrm{C}$ to $308^{\circ} \mathrm{C}$ of stage II, from $230^{\circ} \mathrm{C}$ to $294^{\circ} \mathrm{C}$ of stage III, and eventually from $144^{\circ} \mathrm{C}$ to $233^{\circ} \mathrm{C}$ of stage IV) and salinities. FIs data from the Chuduoqu $\mathrm{Pb}-\mathrm{Zn}-\mathrm{Cu}$ deposit suggest a simple cooling process from stage I to stage II and a mixing process from stage II to stage IV (Figure 10); small scale fluid boiling did take place in stage III.

\subsection{Source of the Ore-Forming Materials}

Sulfur isotopes are the main mineralizing agents for sulfophile elements precipitated as sulfides and also play an important role in the precipitation and enrichment of the metallogenic material [53]. Of the sulfide samples from the Chuduoqu $\mathrm{Pb}-\mathrm{Zn}$-Cu deposit, the chalcopyrite has higher $8^{34} \mathrm{~S}_{\mathrm{CDT}}$ values than the galena. The chalcopyrite formed earlier than the other sulfides, and the $\delta^{34} S_{C D T}$ values of the sulfides decreases systematically according to the established order of sulfide formation, implying that the main mineralization stage of the Chuduoqu deposit developed in a stable and uniform hydrothermal environment, reflecting the characteristics of fractional crystallization under equilibrium conditions.

The $\delta^{34} \mathrm{~S}_{\mathrm{CDT}}$ values of the sulfides in the Chuduoqu $\mathrm{Pb}-\mathrm{Zn}$-Cu deposit range from $-3.8 \%$ o to $2.9 \%$, with a mean value of $-0.5 \%$, showing that the source of $S$ was homogeneous (Figure 12 ). The narrow range of $\delta^{34} \mathrm{~S}_{\mathrm{CDT}}$ values for the ores indicates a magmatic signature [64,65]. The same processes were likely responsible in the formation of other deposits in the northern part of the Sanjiang Metallogenic Belt, as inferred from the consistency in S isotope data for the Quemocuo $\mathrm{Pb}-\mathrm{Zn}$ deposit 
(2.3-3.4\%o, [13]), the Nariniya Pb-Zn deposit (-0.1-1.8\%o, [66]), and the Narigongma porphyry Cu-Mo deposit (3.9-8.0\%o, [67]) (Figure 12).

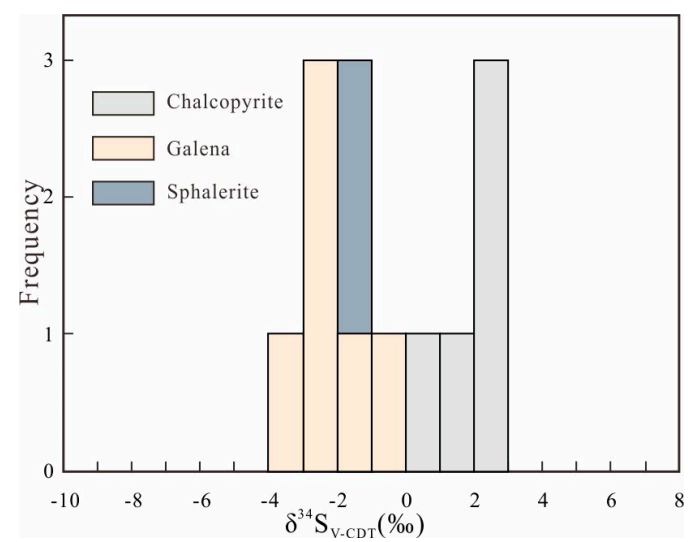

Figure 12. The Sulfur isotope histogram of the Chuduoqu $\mathrm{Pb}-\mathrm{Zn}-\mathrm{Cu}$ deposit. $\delta^{34} \mathrm{~S}$ values of mantle, sedimentary rock, metamorphic rock and meteorite are quoted from [53].

In the diagram of $\mathrm{Pb}$ isotopic compositions (Figure 13), the samples all plot in the area between the orogenic belt and upper crust fields and along the line of orogenic belt evolution. These data indicate that the metallogenic material originated from the upper crust and the denudation of an orogenic belt.
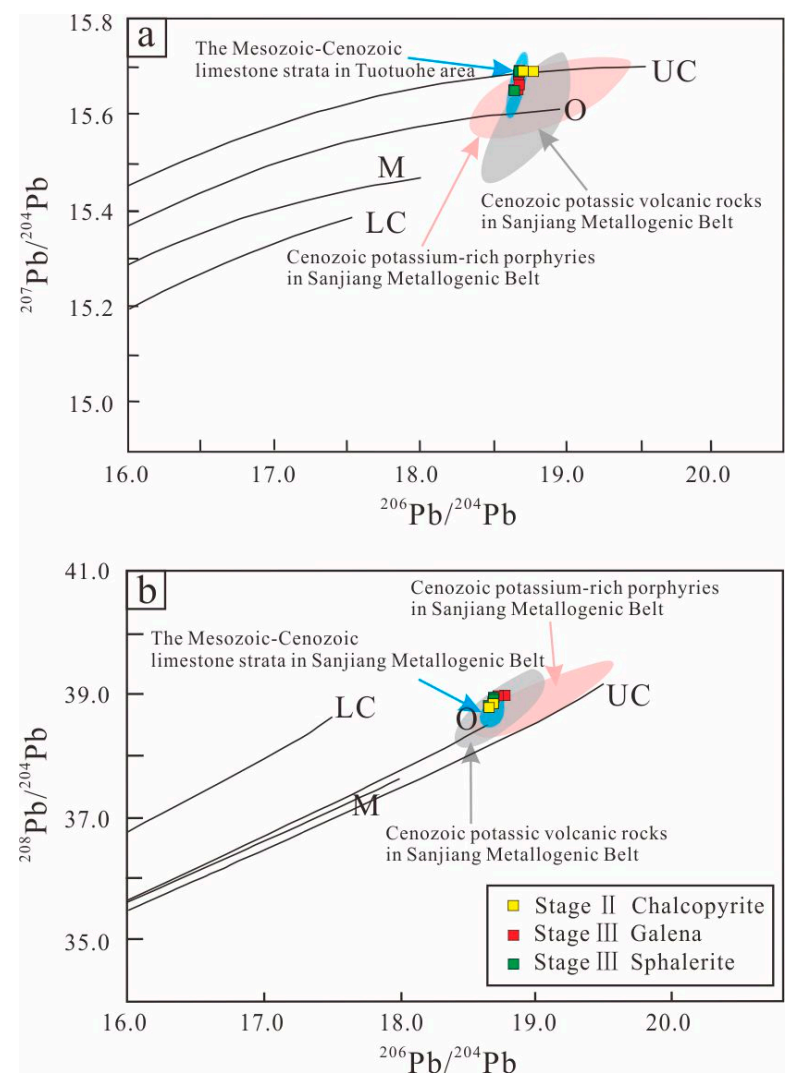

Figure 13. Lead isotope compositions for sulfides in the Chuduoqu $\mathrm{Pb}-\mathrm{Zn}-\mathrm{Cu}$ deposit. (a) ${ }^{207} \mathrm{~Pb} /{ }^{204} \mathrm{~Pb}$ versus ${ }^{206} \mathrm{~Pb} /{ }^{204} \mathrm{~Pb}$ plot; (b) ${ }^{208} \mathrm{~Pb} /{ }^{204} \mathrm{~Pb}$ versus ${ }^{206} \mathrm{~Pb} / 204 \mathrm{~Pb}$ plot. UC - upper crust, $\mathrm{O}$ - orogen, $\mathrm{M}$-mantle, LC-lower crust. The average growth curve is from Zartman and Doe [68]. The field of Cenozoic potassic volcanic rocks in Sanjiang Metallogenic Belt are from [69-73]; the field of Cenozoic potassium-rich porphyries in Sanjiang Metallogenic Belt are from [74,75], the field of Mesozoic-Cenozoic limestone strata are from [76]. 
A discontinuous high- $\mathrm{K}$ igneous province, controlled by intracontinental orogenesis [3] and crustal deformation, developed on the Tibetan Plateau during the late stage of India-Asia collision. These K-rich porphyries and associated K-rich volcanic rocks occur mainly in the central and eastern regions of the plateau, where mineralization is well developed. This high-K magmatism has been dated at $40-24 \mathrm{Ma}[3,26,77]$ with a peak in activity at $35 \pm 5 \mathrm{Ma}$ [3]. Given the above, and regarding the source of metallogenic materials, previous studies have proposed a genetic relationship between the Cenozoic potassic magmatism [13,78] and the occurrence of $\mathrm{Pb}-\mathrm{Zn}$ deposits in the northern part of the Sanjiang Metallogenic Belt. To further investigate this, we collated Pb isotope composition data for Mesozoic and Cenozoic limestone [76], Cenozoic potassic volcanic rock [69-73], and Cenozoic K-rich porphyry $[74,75]$ in the Sanjiang region. The $\mathrm{Pb}$ isotope composition data for the ore in the Chuduoqu $\mathrm{Pb}-\mathrm{Zn}$-Cu deposit fall into the range of potassic magmatic rocks, and the Mesozoic-Cenozoic limestones in the Tuotuohe Basin have similar Pb isotope compositions to those of the Chuduoqu ore. Therefore, we infer that the dominant metallogenic source of the Chuduoqu deposit was a regional-scale potassic magmatic hydrothermal fluid system, with the ore-bearing Jurassic carbonate rocks providing a lesser contribution of metallogenic material.

The $\mathrm{S}$ and $\mathrm{Pb}$ isotopic compositions measured in the present study imply that the material source of the Chuduoqu $\mathrm{Pb}-\mathrm{Zn}-\mathrm{Cu}$ deposit was related to deep magmatic activity. Specifically, the formation of the ores was likely controlled by the syenite porphyry dykes, which are exposed in the study area, and possibly by other rocks at deep levels. The dyke and other igneous rocks provided both the heat source and the main metallogenic material for the formation of the Chuduoqu $\mathrm{Pb}-\mathrm{Zn}-\mathrm{Cu}$ deposit.

\subsection{P-T Conditions of Ore Deposition}

The trapping pressure of FIs can only be estimated when the actual trapping temperature is known, or if fluid boiling or immiscibility was occurring in the system at the time of entrapment (i.e., coeval liquid and/or saline- and vapor-rich inclusions with identical homogenization temperatures) [49,79]. As discussed earlier, in stage III, Liquid-rich (L-type) FIs are spatially associated with vapor-rich (V-type) FIs with similar homogenization temperatures and distinct salinities (Figure 6d). Petrographic and microthermometric data suggest that fluid boiling may take place in stage III. These conditions represent the best estimate of the ore-forming conditions in the Chuduoqu $\mathrm{Pb}-\mathrm{Zn}-\mathrm{Cu}$ deposit, the homogenization temperatures are interpreted to closely approximate the trapping temperatures [79]. Also, Roedder and Bodnar [80] assert that the presence of cations other than $\mathrm{Na}^{+}$have little effect on the slopes of isochors and vapor pressure as compared to the $\mathrm{NaCl}-\mathrm{H}_{2} \mathrm{O}$. According to the formula given by Driesner and Heinrich [81], the trapping pressures during the ore-forming stage III are estimated to range from $\sim 3$ to $8 \mathrm{MPa}$ and are mostly concentrated at $5 \mathrm{MPa}$ (Figure 14), which would correspond to depths of $0.3-0.8 \mathrm{~km}$ assuming hydrostatic conditions [82]. Hence, the initial $\mathrm{Pb}-\mathrm{Zn}$ mineralization in the Chuduoqu $\mathrm{Pb}-\mathrm{Zn}-\mathrm{Cu}$ deposit mainly occurred at depths of less than $0.8 \mathrm{~km}$, which is a shallow mineralization depth. 


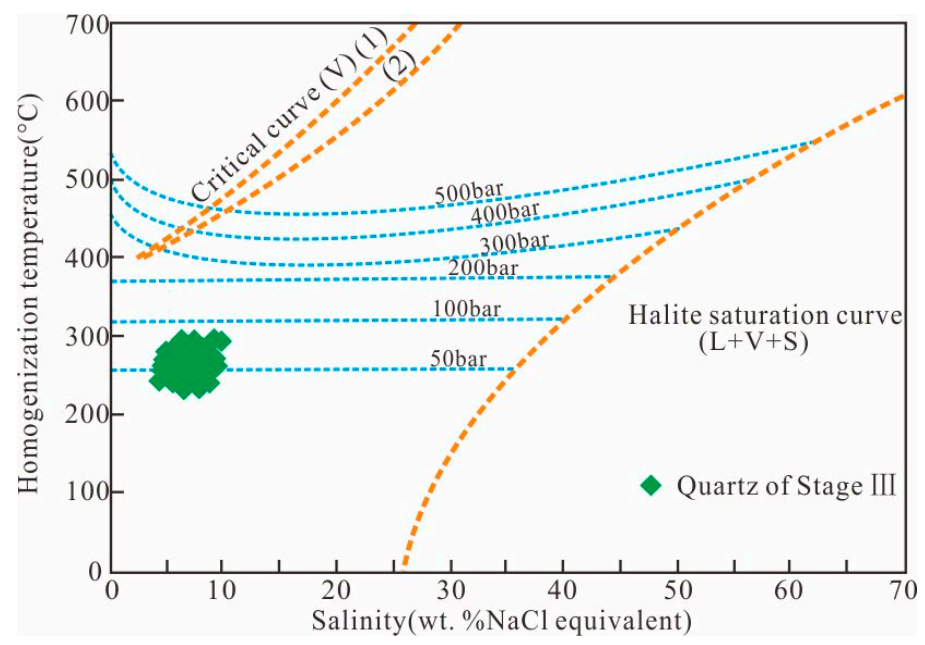

Figure 14. Trapping pressure estimation diagram. Summary plot of homogenization temperatures and salinities of FIs for the Chuduoqu $\mathrm{Pb}-\mathrm{Zn}-\mathrm{Cu}$ deposit. Vapor-liquid coexistence curves were calculated from the equations of Driesner and Heinrich [81].

\subsection{Ore Precipitation Mechanism}

Experimental research has shown that $\mathrm{Cu}, \mathrm{Pb}$ and $\mathrm{Zn}$ are transported as bisulfide complexes at high temperature, but as chloride complexes at low temperature in both low- and high-salinity fluids [83]. Taking into consideration that the fluid inclusions of the Chuduoqu $\mathrm{Pb}-\mathrm{Zn}-\mathrm{Cu}$ deposit are characterized by medium to low temperature $\left(370-144{ }^{\circ} \mathrm{C}\right)$, it is likely that the copper, lead and zinc were transported mainly by chloride complexes of $\mathrm{Pb}^{2+}, \mathrm{Zn}^{2+}$ and $\mathrm{Cu}^{2+}$ in the ore-forming fluids.

Magmatic-hydrothermal deposits are formed by the instability of metal complexes $[84,85]$. The precipitation of sulfides from ore-forming fluids may be triggered by boiling [86,87], fluid mixing [88], cooling [89] and fluid-rock interaction [90].

Mineralization stage I: The FIs and $\mathrm{H}-\mathrm{O}$ isotope compositional data indicate that the fluids were released from magma. As the temperature dropped to $370{ }^{\circ} \mathrm{C}$, specularite and quartz started to precipitate.

Mineralization stage II: The fluids migrated upwards, and the temperature dropped below $308^{\circ} \mathrm{C}$. The ore-forming fluids were mixed with meteoric water from stage II to stage II according to the discussion in Section 7.1. The results show that the ore-forming fluids were diluted by external meteoric fluids with moderate temperatures and salinities, which is related to the deposition of copper-rich sulfide [91]. Fluid mixing between magmatic fluids and meteoric water could play an important role in the deposition of metals from ore-forming fluids [90]. In addition, the precipitation of specularite in stage II increased the $\mathrm{Cu} / \mathrm{Fe}$ ratio, which changed the sulfur from $\mathrm{S}^{6+}\left(\mathrm{S}^{4+}\right)$ to $\mathrm{S}^{2+}$, and reduced the solubility of copper in the fluids [92]. This was the main stage of $\mathrm{Cu}$ formation.

Mineralization stage III: Small scale fluid boiling occurred in some quartz from stage III; however, no boiling fluid inclusion assemblage was observed in other stages. The results show that fluid boiling was not the key factor to control the precipitation of lead, zinc and copper in the Chuduoqu $\mathrm{Pb}-\mathrm{Zn}-\mathrm{Cu}$ deposit. Fournier [93] believed that fluid cooling, along with the decrease of in temperature, salinity and pressure, increases the activity of $\mathrm{S}^{2-}$, and decomposition of the metal complex [94], may have been the most likely ore precipitation mechanism. As shown in Figure 10, the salinities of the ore-forming fluids in the Chuduoqu $\mathrm{Pb}-\mathrm{Zn}$-Cu deposit decreased with decreasing homogenization temperatures from stage I to stage IV. It is suggested that the cooling might be an important factor for the formation of $\mathrm{Pb}-\mathrm{Zn}$ ore bodies. The sulfides could form by the following reactions:

$$
\mathrm{ZnCl}^{+}+\mathrm{HS}^{-} \rightarrow \mathrm{ZnS} \text { (sphalerite) }+\mathrm{H}^{+}+\mathrm{Cl}^{-}
$$




$$
\mathrm{PbCl}_{4}{ }^{2-}+\mathrm{HS} \rightarrow \mathrm{PbS} \text { (galena) }+\mathrm{H}^{+}+4 \mathrm{Cl}^{-}
$$

This was the main stage of $\mathrm{Pb}$ and $\mathrm{Zn}$ formation.

Mineralization stage IV: The ore-forming fluids migrated to the shallow subsurface. As the temperature dropped further, low-temperature sulfides such as pyrite were formed. The meteoric water could easily blend into the hydrothermal system because boiling of the ore fluids in stage III helps open the conduits and increases the permeability of the host rocks.

\subsection{Metallogenic Model}

Many geological and geochemical features of the Chuduoqu $\mathrm{Pb}-\mathrm{Zn}-\mathrm{Cu}$ deposit are consistent with the Cordilleran-type vein deposits [95-97]. These features include the following: (1) The deposit was formed in extensional faults; (2) The main metallogenic stage veins are rich in sulfide; (3) Vein formation is mainly under epithermal conditions at shallow levels (less than $0.8 \mathrm{~km}$ for the initial $\mathrm{Pb}-\mathrm{Zn}$ mineralization, assuming hydrostatic conditions at Chuduoqu); (4) The hydrothermal fluids were characterized by medium to low salinity and temperatures below $370{ }^{\circ} \mathrm{C}$; (5) The deposit have close spatial, temporal and genetic relationship with porphyry systems; (6) The ore-forming fluids were derived from a magmatic-hydrothermal system. However, the Chuduoqu $\mathrm{Pb}-\mathrm{Zn}$ - $\mathrm{Cu}$ deposit also has some different characteristics as compared with the Cordilleran-type vein deposits. The differences include: (1) The Cordilleran-type deposits generally have a well-developed metal and alteration zonation in deposit scale [96], on the contrary, the Chuduoqu Pb-Zn-Cu deposit has no obvious metal and alteration zonation; (2) $\mathrm{Cu}-\mathrm{Zn}-\mathrm{Pb}-\mathrm{Au}-\mathrm{Ag}-(\mathrm{Bi}-\mathrm{Sb})$ is a metal assemblage in the Cordilleran-type deposits, in which $\mathrm{Au}$ is a common metal element [97], whereas the Chuduoqu $\mathrm{Pb}-\mathrm{Zn}$ - $\mathrm{Cu}$ deposit contain $\mathrm{Cu}-\mathrm{Pb}-\mathrm{Zn}-\mathrm{Ag}$ without Au.

Hou et al. [3] analyzed collisional orogenesis on the Tibetan Plateau and identified three stages: primary collision (65-41 Ma), late collision (40-26 Ma), and post collision (25-0 Ma). India-Eurasia plate collision began at around $65 \mathrm{Ma}$, and the India plate was subducted northward until $41 \mathrm{Ma}$ [2], causing $\mathrm{N}-\mathrm{S}$-directed tectonic compression [17,98,99] and accommodating at least $61 \mathrm{~km} \mathrm{[4]} \mathrm{of} \mathrm{shortening}$ as well as forming a continental crust of twice the normal thickness. The shortening is ongoing [100].

During the late collision stage from $40 \mathrm{Ma}$, the thickened orogen was subjected to large-scale extension resulting from differentials in gravity potential and delamination. As a result of the gravitational instability, the lower crust and lithosphere mantle were removed and sunk together to the asthenosphere mantle. Subsequently, asthenosphere upwelling heated the lower-crust and upper-mantle rocks, leading to their partial melting. The resultant magma was a mixture of these partially melted rocks. The upwelling of magma along deep fractures and large-scale extensional faults formed volcanic, sub-intrusive, and intrusive rocks throughout the Sanjiang region. Ore-forming fluids were released from the magma as a result of decompression during ascent to shallower depths in the later stages of intrusive magma evolution. Phase-separated fluids mixed with meteoric water and exchanged material with surrounding rocks, then migrated to shallower regions to deposit various minerals. Disseminated and veinlet mineralization occurred during hydraulic fracturing when the ore-bearing fluids circulated around the hypabyssal intrusive mass, forming porphyry-type Cu polymetallic mineralization, such as that found in the Zhalaxiageyong, Nariniya, and Zhamuqu deposits. Ore-bearing fluids upwelled to shallower depths along deep fractures, and vein mineralization occurred along shallow extensional fractures, forming the Chuduoqu mesothermal hydrothermal vein $\mathrm{Pb}-\mathrm{Zn}-\mathrm{Cu}$ deposit (Figure 15). 




Figure 15. Metallogenic model for the Chuduoqu $\mathrm{Pb}-\mathrm{Zn}-\mathrm{Cu}$ deposit.

\section{Conclusions}

(1) The ores of the Chuduoqu $\mathrm{Pb}-\mathrm{Zn}-\mathrm{Cu}$ deposit in central Tibet are hosted in limestone and sandstone of the Middle Jurassic Xiali Formation $\left(\mathrm{J}_{2} x\right)$ and are structurally controlled by NWW-trending faults cutting the host sediments. The mineralization of the Chuduoqu $\mathrm{Pb}-\mathrm{Zn}-\mathrm{Cu}$ deposit can be divided into four stages: quartz-specularite (stage I), quartz-barite-chalcopyrite (stage II), quartz-polymetallic sulfide (stage III), and quartz-carbonate (stage IV).

(2) $\mathrm{H}, \mathrm{O}, \mathrm{C}, \mathrm{S}$, and $\mathrm{Pb}$ isotope data of samples from the Chuduoqu deposit reveal that the ore-forming fluids had a dominantly magmatic signature but were mixed with meteoric water. The most likely source of metallogenic material was a regional-scale potassic magmatic hydrothermal fluid system, and the mineralization occurred between 40 and 24 Ma. Specifically for the Chuduoqu $\mathrm{Pb}-\mathrm{Zn}-\mathrm{Cu}$ deposit, the magmatic activity of a syenite porphyry intrusion most probably provided the heat source and main metallogenic material for the mineralization.

(3) Fluid mixing and cooling mainly contributed to the ore precipitation. In addition, small scale fluid boiling did take place in some quartz from stage III.

(4) The Chuduoqu $\mathrm{Pb}-\mathrm{Zn}-\mathrm{Cu}$ deposit is a mesothermal hydrothermal vein deposit and shares many similar features with those of Cordilleran-type vein deposits worldwide, and it was formed in an extensional environment related to late intracontinental orogenesis caused by India-Asia collision.

Supplementary Materials: The following are available online at http://www.mdpi.com/2075-163X/9/5/285/s1, Table S1: Characteristics of main ore bodies in the Chuduoqu Pb-Zn-Cu deposit.

Author Contributions: Conceptualization, Y.S., B.L. and F.S.; Software, R.Y. and T.Z.; Investigation, Y.S., B.L., F.S., Y.Q. and J.D.; Data curation, R.Y. and T.Z.; Funding acquisition, B.L.; Project administration, B.L.; Writing一original draft preparation, Y.S.; Writing-review and editing, Y.S. and B.L.

Funding: This research was funded by Geological Survey Project (12120114080901) of China Geological Survey and the National Natural Science Foundation of China (41272093 and 41272095).

Acknowledgments: We would like to thank the Analysis and Testing Research Center of Nuclear Industry, Beijing Institute of Geology, Beijing, China, and the Experimental Center of Testing Science, Jilin University, China for helping in the analyses.

Conflicts of Interest: The authors declare no conflict of interest. 


\section{References}

1. Zhu, D.C.; Zhao, Z.D.; Niu, Y.L.; Dilek, Y.; Hou, Z.Q.; Mo, X.X. The origin and pre-Cenozoic evolution of the Tibetan Plateau. Gondwana Res. 2013, 23, 1429-1454. [CrossRef]

2. Hou, Z.Q.; Song, Y.C.; Li, Z.; Wang, Z.L.; Yang, Z.M. Thrust-controlled, sediments-hosted Pb-Zn-Ag-Cu deposits in eastern and northern margins of Tibetan orogenic belt: Geological features and tectonic model. Miner. Depos. 2008, 27, 123-144. (In Chinese)

3. Hou, Z.Q.; Pan, G.T.; Wang, A.J.; Mo, X.X.; Tian, S.H. Metallogenesis in Tibetan collisional orogenic belt: II. Mineralization in late-collisional transformation setting. Miner. Depos. 2006, 25, 521-543. (In Chinese)

4. Spurlin, M.S.; Yin, A.; Horton, B.K.; Zhou, J.; Wang, J. Structural evolution of the Yushu-Nangqian region and its relationship to syncollisional igneous activity, east-central Tibet. Geol. Soc. Am. Bull. 2005, 117, 1293-1317. [CrossRef]

5. Liu, D.; Zhao, Z.D.; Zhu, D.C.; Niu, Y.; DePaolo, D.J.; Harrison, T.M.; Mo, X.; Dong, G.; Zhou, S.; Sun, C.; et al. Postcollisional potassic and ultrapotassic rocks in southern Tibet: Mantle and crustal origins in response to India-Asia collision and convergence. Geochim. Cosmochim. Acta 2014, 143, 207-231. [CrossRef]

6. Deng, J.; Wang, Q.F. Gold mineralization in China: Metallogenic provinces, deposit types and tectonic framework. Gondwana Res. 2016, 36, 219-274. [CrossRef]

7. Li, G.J.; Wang, Q.F.; Huang, Y.H.; Gao, L.; Li, Y. Petrogenesis of Middle Ordovician peraluminous granites in the Baoshan block: Implications for the Early Paleozoic tectonic evolution along East Gondwana. Lithosphere 2016, 245, 76-92. [CrossRef]

8. Xue, C.J.; Wang, R.; Liu, S.W.; Chi, G.X.; Qing, H.R.; Chen, Y.C.; Yang, J.M.; Wang, D.H. Geologic, fluid inclusion and isotopic characteristics of the Jinding $\mathrm{Zn}-\mathrm{Pb}$ deposit, western Yunnan, South China: A review. Ore Geol. Rev. 2007, 31, 337-359. [CrossRef]

9. He, L.Q.; Song, Y.C.; Chen, K.X.; Hou, Z.Q.; Yu, F.M.; Yang, Z.S.; Wei, J.Q.; Li, Z.; Liu, Y.C. Thrust-controlled, sediment-hosted, Himalayan $\mathrm{Zn}-\mathrm{Pb}-\mathrm{Cu}-\mathrm{Ag}$ deposits in the Lanping foreland fold belt, eastern margin of Tibetan Plateau. Ore Geol. Rev. 2009, 36, 106-132. [CrossRef]

10. Liu, Y.C.; Hou, Z.Q.; Yang, Z.S.; Tian, S.; Song, Y.; Yu, Y.; Ma, W. Geology and chronology of the Zhaofayong carbonate-hosted $\mathrm{Pb}-\mathrm{Zn}$ ore cluster: Implication for regional $\mathrm{Pb}-\mathrm{Zn}$ metallogenesis in the Sanjiang belt, Tibet. Gondwana Res. 2016, 35, 15-26. [CrossRef]

11. Liu, Y.C.; Hou, Z.Q.; Yang, Z.S.; Tian, S.H.; Yang, T.N.; Song, Y.C.; Zhang, H.R.; Carranza, E.J.M. Formation of the Dongmozhazhua $\mathrm{Pb}-\mathrm{Zn}$ deposit in the thrust-fold setting of the Tibetan plateau, China: Evidence from fluid inclusion and stable isotope data. Resour. Geol. 2011, 61, 384-406. [CrossRef]

12. Liu, Y.C.; Yang, Z.S.; Tian, S.H.; Song, Y.C.; Zhang, H.R. Fluid origin of fluorite-rich carbonate-hosted Pb-Zn mineralization of the Himalayan-Zagros collisional orogenic system: A case study of the Mohailaheng deposit, Tibetan Plateau, China. Ore Geol. Rev. 2015, 70, 546-561. [CrossRef]

13. Qian, Y. Metallogenic Setting and Metallogenesis Lead and Zinc in Tuotuohe Region, Qinghai-Tibet Plateau. Ph.D. Thesis, Jilin University, Changchun, China, 2014. (In Chinese).

14. Song, Y.C.; Hou, Z.Q.; Wang, G.R.; Liu, Y.C.; Tian, S.H.; Yang, Z.S.; Liu, Y.X.; Zhang, H.R.; Yang, T.N.; LI, L.S. Metallogenic regularity and ore exploration targeting in Tuotuohe area, northern Sanjiang orogenic belt. Miner. Depos. 2015, 1, 1-20. (In Chinese)

15. Sun, Y.G. Study on Ore-Controlling Structure Characteristics and Ore Genesis of Chuduoqu Lead-Zinc Mine in Tuotuohe Region, Qinghai Province. Master's Thesis, Jilin University, Changchun, China, 2016. (In Chinese).

16. Song, Y.C.; Yang, T.N.; Zhang, H.R.; Liu, Y.C.; Hao, H.D.; Li, Z. The Chaqupacha Mississippi Valley-type $\mathrm{Pb}-\mathrm{Zn}$ deposit, central Tibet: Ore formation in a fold and thrust belt of the India-Asia continental collision zone. Ore Geol. Rev. 2015, 70, 533-545. [CrossRef]

17. Yin, A.; Harrison, T.M. Geologic Evolution of the Himalayan-Tibetan Orogen. Annu. Rev. Earth Planet. Sci. 2000, 28, 211-280. [CrossRef]

18. Li, Y.L.; Wang, C.S.; Zhao, X.X.; Yin, A.; Ma, C. Cenozoic thrust system, basin evolution, and uplift of the Tanggula Range in the Tuotuohe region, central Tibet. Gondwana Res. 2012, 22, 482-492. [CrossRef]

19. Yang, T.N.; Zhang, H.R.; Liu, Y.X.; Wang, Z.L.; Song, Y.C.; Yang, Z.S.; Tian, S.H.; Xie, H.Q.; Hou, K.J. Permo-Triassic arc magmatism in central Tibet: Evidence from zircon U-Pb geochronology, Hf isotopes, rare earth elements, and bulk geochemistry. Chem. Geol. 2011, 284, 270-282. [CrossRef] 
20. Yang, T.N.; Hou, Z.Q.; Wang, Y.; Zhang, H.R.; Wang, Z.L. Late Paleozoic to Early Mesozoic tectonic evolution of northeast Tibet: Evidence from the Triassic composite western Jinsha-Garzê-Litang suture. Tectonics 2012, 31, 1-20. [CrossRef]

21. Li, Y.L.; Wang, C.S.; Ma, C.; Xu, G.Q.; Zhao, X.X. Balanced cross-section and crustal shortening analysis in the Tanggula-Tuotuohe area, northern Tibet. J. Earth. Sci. 2011, 22, 1-10. [CrossRef]

22. Zhang, Y.X.; Zhang, K.J.; Li, Y.; Li, B.; Xie, Y. Characteristics and sedimentary facies of the Middle-Upper Jurassic clastic rocks in Qiangtang Basin, Tibet. Geo Meta. 2007, 31, 51-62. (In Chinese)

23. Qian, Y.; Sun, F.Y.; Li, B.L.; Li, S.J.; Zhao, J.W. Early Permian-Late Triassic Magmatism in the Tuotuohe Region of the Qinghai-Tibet Plateau: Constraints on the Tectonic evolution of the Western Segment of the Jinshajiang Suture. Acta Geol. Sin. 2014, 88, 498-516. (In Chinese) [CrossRef]

24. Hao, H.D.; Song, Y.C.; Li, L.S.; Jia, Z.Y.; Wang, Y.K.; Liu, Q. Characteristics of Breccias and C-O-Sr-S Isotope Geochemistry of the Duocaima $\mathrm{Pb}-\mathrm{Zn}$ Deposit in Tuotuohe, Qinghai Province: Implications for the Ore-forming Process. Acta Geol. Sin. 2015, 89, 1568-1587. (In Chinese)

25. Li, Y.L.; Wang, C.S.; Yi, H.S.; Liu, Z.F.; Li, Y. Cenozoic Thrust System and Uplifting of the Tanggula Mountain, Northern Tibet. Acta Geol. Sin. 2006, 80, 1118-1130. (In Chinese)

26. Wang, J.H.; Yin, A.; Harrison, T.M.; Grove, M.; Zhang, Y.Q.; Xie, G.H. A tectonic model for Cenozoic igneous activities in the eastern Indo-Asian collision zone. Earth Planet Sci. Lett. 2001, 188, 123-133. [CrossRef]

27. Ding, L.; Zhou, Y.; Zhang, J.J.; Deng, W.M. Geologic relationships and geochronology of the Cenozoic volcanoes and interbedded weathered mantles of Yulinshan in Qiangtang, North Tibet. Chin. Sci. Bull. 2000, 45, 2214-2220. (In Chinese) [CrossRef]

28. Lai, S.C.; Liu, C.Y.; O'Reilly, S.Y. Petrogenesis and its significance to continental dynamics of the Neogene high-potassium calc-alkaline volcanic rock association from north Qiangtang, Tibetan Plateau. Sci. Chin. Ser. D 2001, 44, 44-45. (In Chinese) [CrossRef]

29. Xia, L.Q.; Li, X.M.; Ma, Z.P.; Xu, X.Y.; Xia, Z.C. Cenozoic volcanism and tectonic evolution of the Tibetan plateau. Gondwana Res. 2010, 19, 850-866. [CrossRef]

30. Li, Z. The ore Forming Genesis Research of Chaqupacha Lead-Zinc Deposits in Qinghai Province Tuotuohe Area. Master's Thesis, Beijing University of Science and Technology, Beijing, China, 2008. (In Chinese).

31. Sun, J.; Li, B.L.; Zhao, G.Q.; Liu, Y.F.; Zhang, J.Y. Zircon U-Pb chronology and geochemistry of Basihu diorite in Tuotuohe area,Qinghai-Tibetan Plateau. J. Guilin Univ. Technol. 2018, 38, 25-33. (In Chinese)

32. Duan, Z.M.; Li, Y.; Zhang, Y.; Li, Y.L.; Wang, M. Zircon U-Pb age, continent dynamics significance and geochemical characteristics of the Mesozoic and Cenozoic granites from the Tanggula Range in the Qinghai-Tibet plateau. Acta Geol. Sin. 2005, 79, 88-97. (In Chinese)

33. Li, L.; Bai, Y.S.; Niu, Z.J.; Yao, H.Z.; Duan, Q.F. The ultrabasic and basic rocks and their tectonic settings in the Qoimaco region, Qiangtang on the Qinghai-Xizang Plateau. Se. Geo. Teth. Geo. 2004, 24, 27-34. (In Chinese)

34. Wang, G.Z. Study on Geological Features and Genetic of Zhalaxiageyong Cu-Pb-Zn Deposit in the Tuotuohe Area, Qinghai. Master's Thesis, Jilin University, Changchun, China, 2017. (In Chinese).

35. Roger, F.; Tapponnier, P.; Arnaud, N.; Schärer, U.; Brunel, M.; Zhiqin, X.; Jingsui, Y. An Eocene magmatic belt across central Tibet: Mantle subduction triggered by the Indian collision. Terra Nova. 2000, 12, 102-108. [CrossRef]

36. Roedder, E. Fluid inclusions. Rev. Miner. 1984, 12, 1-644.

37. Clayton, W.M.; Mayeda, T.K. The use of bromine pent a fluoride in the extraction of oxygen from oxides and silicates for isotopic analysis. Geochim. Cosmochim. Acta 1963, 27, 43-52. [CrossRef]

38. Friedman, I. Deuterium content of natural waters and other substances. Geochim. Cosmochim. Acta 1953, 4, 89-103. [CrossRef]

39. McCrea, J.M. On the isotopic chemistry of carbonates and a paleotemperature scale. J. Chem. Phys. 1950, 18, 849-857. [CrossRef]

40. Friedman, I.; O'Neil, J.R. Complication of Stable Isotope Fractionation Factors of Geochemical Interest. In Data of Geochemistry — Sixth Edition; Fleischer, M., Ed.; US Government Printing Office: Washington, DC, USA, 1977.

41. Hall, D.L.; Sterner, S.M.; Bodnar, R.J. Freezing point depression of NaCl-KCl-H $\mathrm{H}_{2} \mathrm{O}$ solutions. Econ. Geol. 1988, 83, 197-202. [CrossRef] 
42. Crawford, M.L. Phase equilibria in aqueous fluid inclusions. In Fluid Inclusions: Application to Petrology; Hollister, L.S., Crawfor, M.L., Eds.; Mineralogical Association of Canada: Quebec City, QC, Canada, 1981; Volume 83, pp. 197-202.

43. Bodnar, R.J. Revised equation and table for determining the freezing point depression of $\mathrm{H}_{2} \mathrm{O}-\mathrm{NaCl}$ solutions. Geochim. Cosmochim. Acta 1993, 57, 683-684. [CrossRef]

44. Clayton, R.N.; O’Neil, J.R.; Mayeda, T.K. Oxygen Isotope Exchange between Quartz and Water. J. Geophys. Res. 1972, 77, 3057-3067. [CrossRef]

45. Taylor, H.P. The Application of Oxygen and Hydrogen Isotope Studies to Problems of Hydrothermal Alteration and Ore Deposition. Econ. Geol. 1974, 69, 843-883. [CrossRef]

46. Barnes, H.L. Solubilities of ore minerals. In Geochemistry of Hydrothermal Ore Deposits; Barnes, H.L., Ed.; Wiley: New York, NY, USA, 1979; pp. 404-460.

47. Rye, R.O.; Ohmoto, H. Sulfur and carbon isotopes and ore genesis: A review. Econ. Geol. 1974, 69, 826-842. [CrossRef]

48. Hedenquist, J.W.; Arribas, A.; Reynolds, T.J. Evolution of an intrusion- centered hydrothermal system: Far southeast-lepanto porphyry and epithermal Cu-Au deposits, Philippines. Econ. Geol. 1998, 93, 373-404. [CrossRef]

49. Shepherd, T.J.; Rankin, A.H.; Alderton, D.H.M. A Practical Guide to Fluid Inclusion Studies; Blackie and Son Ltd.: London, UK, 1985.

50. Taylor, B.E. Magmatic volatiles: Isotope variation of C, H and S. Rev. Miner. Geochem. 1986, 16, $185-225$.

51. Demény, A.; Ahijado, A.; Casillas, R.; Vennemann, T.W. Crustal contamination and fluid/rock interaction in the carbonatites of Fuerteventura (Canary Islands, Spain): A C, O, H isotope study. Lithosphere 1998, 44, 101-115. [CrossRef]

52. Baker, A.J.; Fallick, A.E. Evidence from Lewisian limestones for isotopically heavy carbon in two-thousand-million-year-old sea water. Nature 1989, 337, 352-354. [CrossRef]

53. Hoefs, J. Stable Isotope Geochemistry (4); Springer: Berlin, Germany, 1997; pp. 199-201.

54. Taylor, H.P.; Frechen, J.; Degens, E.T. Oxygen and carbon isotope studies of carbonatites from the Laacher See District, West Germany and the Alnö District, Sweden. Geochim. Cosmochim. Acta 1967, 31, 407-430. [CrossRef]

55. Ray, J.S.; Ramesh, R.; Pande, K. Carbon isotopes in Kerguelen plume-derived carbonatites: Evidence for recycled inorganic carbon. Earth Planet. Sci. Lett. 1999, 170, 205-214. [CrossRef]

56. Hudson, J.D. Stable isotopes and limestone lithification. J. Geol. Soc. 1977, 133, 637-660. [CrossRef]

57. Deines, P. Stable isotope variations in carbonatites. In Carbonatites: Genesis and Evolution; Bell, K., Ed.; Unwin Hyman: London, UK, 1989; pp. 301-359.

58. Demeny, A.; Harangi, S.Z. Stable isotope studies on carbonate formations in alkaline basalt and lamprophyre series: Evolution of magmatic fluids and magma-sediment interactions. Lithosphere 1996, 37, 335-349.

59. Hoernle, K.; Tilton, G.; Le Bas, M.J.; Duggen, S.; Garbe-Schönberg, D. Geochemistry of oceanic carbonatites compared with continental carbonatites: Mantle recycling of oceanic crustal carbonate. Contrib. Miner. Petrol. 2002, 142, 520-542. [CrossRef]

60. Lorrain, A.; Savoye, N.; Chauvaud, L.; Paulet, Y.M.; Naulet, N. Decarbonation and preservation method for the analysis of organic $\mathrm{C}$ and $\mathrm{N}$ contents and stable isotope ratios of low-carbonated suspended particulate material. Anal. Chim. Acta 2003, 491, 125-133. [CrossRef]

61. Chen, F.C.; Deng, J.; Wang, Q.F.; Li, G.J.; Shu, Q.H.; Yang, C.H.; Liu, J.Y.; Xu, R. The source and evolution of ore fluids in the Heiniuwa gold deposit, Baoshan block, Sanjiang region: Constraints from sulfide trace element, fluid inclusion and stable isotope studies. Ore. Geol. Rev. 2018, 95, 725-745. [CrossRef]

62. Bodnar, R.J.; Reynolds, T.J.; Kuehn, C.A. Fluid inclusion systematics in epithermal systems. Rev. Econ. Geol. $1985,2,25$.

63. Heinrich, C.A. Fluid-fluid interactions in magmatic-hydrothermal ore formation. Rev. Mineral. Geochem. 2007, 65, 363-387. [CrossRef]

64. Ohmoto, H. Stable Isotope Geochemistry of Ore Deposits. Rev. Miner. 1986, 16, 491-559.

65. Ripley, E.M. Origin and concentration mechanisms of copper and nickel in Duluth Complex sulfide zones, a dilemma. Econ. Geol. 1986, 81, 974-978. [CrossRef]

66. Zhang, C.; Song, Y.C.; Hou, Z.Q. Geological and geochemical studies of the Nariniya lead-zinc depositin Tuotuohe area, Qinghai Province. Acta Petrol. Miner. 2013, 32, 291-304. (In Chinese) 
67. Li, Y.Z.; Kong, H.L.; Nanka, E.W. Analysis of Matter Source and Metallogenic Setting of Metallogenic Rock of Narigongma Porphyry Copper Molybdenum Deposit in Qinhai Province. Geol. Sci. Technol. Inf. 2015, 34, $1-7$.

68. Zartman, R.E.; Doe, B.R. Plumbotectonics-The model. Tectonophysics 1981, 75, 135-162. [CrossRef]

69. Zhu, B.Q.; Zhang, Y.Q.; Xie, Y.W. Nd, Sr and Pb isotopic characterstics of cenozoic ultra-potassic volcanic rocks from eastern Erhai, Yunnan and their implications for subcontinent-mantle evolution in South China. Geochim 1992, 3, 201-212.

70. Zhang, Y.Q.; Xie, Y.W.; Li, X.H.; Qiu, H.N.; Zhao, Z.H.; Liang, H.Y.; Zhong, S.L. Isotopic characteristics of potassium basalt series magmatic rocks in eastern Qinghai-Tibet Plateau: Petrogenesis and its tectonic significance. Sci. Chin. D 2000, 30, 493-498. (In Chinese)

71. Deng, W.M.; Zhang, H.J.; Zhang, Y.Q. Petrogenesis of cenozoic potassic volcanic rocks in Nangqen basin. Chin. J. Geol. 2001, 36, 304-318. (In Chinese)

72. Zhao, X.; Yu, X.H.; Mo, X.X.; Zhang, J.; Lv, B.X. Petrological and geochemical characteristics of Cenozoic alkali -rich porphyries and xenoliths hosted in Western Yunnan Province. Geoscience 2004, 18, 217-228. (In Chinese)

73. Zhang, C. Study on the metalgenesis of the Nariniya lead-zinc deposits in the Tuotuohe area, Qinghai province. Master's Thesis, East China Institute of Technology, Nanchang, China, 2013. (In Chinese).

74. Hao, J.H.; Chen, J.P.; Dong, Q.J.; Li, Y.L.; Wang, T. Element and Sr-Nd-Pb isotope geochemistry of ore-bearing porphyries in northern Sanjiang $\mathrm{Mo}(\mathrm{Cu})$ ore belt, Qinghai Province: Implications for tectonic setting and petrogenesis. Acta Petrol. Miner. 1998, 30, 427-437. (In Chinese)

75. Yang, Z.M.; Hou, Z.Q.; Yang, Z.S.; Wang, S.X.; Wang, G.R.; Tian, S.H.; Wen, D.Y.; Wang, Z.L.; Liu, Y.C. Genesis of porphyries and tectonic controls on the Narigongma porphyry Mo (-Cu) deposit, southern Qinghai. Acta Petrol. Sin. 2008, 24, 489-502. (In Chinese)

76. Tian, S.H.; Yang, Z.S.; Hou, Z.Q.; Liu, Y.C.; Song, Y.C.; Wang, F.C.; Xue, W.W. Sulfur, lead, strontium and neodymium isotope compositions of the Dongmozhazhua lead-zinc ore deposit in the Yushu area, southern Qinghai: Implications for the sources of ore-forming material in the deposit. Acta Petrol. Sin. 2011, 27, 2173-2183. (In Chinese)

77. Chung, S.L.; Lo, C.H.; Lee, T.Y.; Zhang, Y.; Xie, Y.; Li, X.; Wang, K.L.; Wang, P.L. Diachronous uplift of the Tibetan plateau starting $40 \mathrm{Myr}$ ago. Nature 1998, 394, 769-773. [CrossRef]

78. Zhao, Z.D.; Mo, X.X.; Dong, G.C. Pb isotopic geochemistry of Tibetan Plateau and its implications. Geoscience 2007, 2, 265-274. (In Chinese)

79. Roedder, E.; Bodnar, R.J. Geologic pressure determinations from fluid inclusion studies. Annu. Rev. Earth Planet. Sci. 1980, 8, 263-301. [CrossRef]

80. Roedder, E.; Bodnar, R.J. Fluid inclusion studies of hydrothermal ore deposits. In Geochemistry of Hydrothermal Ore Deposits; Barnes, H.L., Ed.; Wiley: New York, NY, USA, 1997; pp. 657-697.

81. Driesner, T.; Heinrich, C.A. The system $\mathrm{H}_{2} \mathrm{O}-\mathrm{NaCl}$. Part I: Correlation formulae for phase relations in temperature-pressure-composition space from 0 to $1000{ }^{\circ} \mathrm{C}, 0$ to $5000 \mathrm{bar}$, and 0 to $1 \mathrm{XNaCl}$. Geochim. Cosmochim. Acta 2007, 71, 4880-4901. [CrossRef]

82. Sibson, R.H.; Robert, F.; Poulsen, K.H. High angle reverse faults, fluid-pressure cycling, and mesothermal gold-quartz deposits. Geology 1988, 16, 551-555. [CrossRef]

83. Zhong, R.C.; Brugger, J.; Chen, Y.J.; Li, W.B. Contrasting regimes of $\mathrm{Cu}, \mathrm{Zn}$ and $\mathrm{Pb}$ transport in ore-forming hydrothermal fluids. Chem. Geol. 2015, 154-164, 154-164. [CrossRef]

84. Seward, T.; Barnes, H. Metal transport by hydrothermal ore fluids. In Geochemistry of Hydrothermal Ore Deposits, 3rd ed.; Barnes, H., Ed.; Wiley: New York, NY, USA, 1997; pp. 435-486.

85. Mao, G.Z.; Hua, R.M.; Long, G.M.; Lu, H.J. Rb-Sr Dating of Pyrite and Quartz Fluid Inclusions and Origin of Ore-forming Materials of the Jinshan Gold Deposit, Northeast Jiangxi Province, South China. Acta Geol. Sin. Engl. Ed. 2013, 87, 1658-1667. [CrossRef]

86. Calagari, A.A. Fluid inclusion studies in quartz veinlets in the porphyry copper deposit at Sungun, East-Azarbaidjan, Iran. J. Asian Earth Sci. 2004, 23, 179-189. [CrossRef]

87. Wang, L.L.; Sun, F.Y.; Xu, J.H.; Wang, K.Y.; Wang, L.; Xu, Q.L. Ore-forming fluid and evolution of Luming molybdenum deposit, Heilongjiang Province. Acta Petrol. Sin 2015, 31, 979-990. (In Chinese)

88. O'Neil, J.R.; Silberman, M.L. Stable isotope relations in epithermal Au-Ag deposits. Econ. Geol. 1974, 69, 902-909. [CrossRef] 
89. Landtwing, M.; Pettke, T.; Halter, W.; Heinrich, C.; Redmond, P.; Einaudi, M.; Kunze, K. Copper deposition during quartz dissolution by cooling magmatichydrothermal magmatic-hydrothermal fluids: The Bingham porphyry. Earth Planet. Sci. Lett. 2005, 235, 229-243. [CrossRef]

90. Beane, R.; Titley, S. Porphyry copper deposits; Part II: Hydrothermal alteration and mineralization. Econ. Geol. 1981, 75, 235-269.

91. Partida, E.G.; Chavez, A.A.; Levresse, G.; Tritlla, J.; Camprubi, A. Genetic implications of fluid inclusions in skarn chimney ore, Las Animas Zn-Pb-Ag(-F) deposit, Zimapan, Mexico. Ore. Geol. Rev. 2003, 23, 91-96.

92. Hezarkhani, A.; Williams-Jones, A.E.; Gammons, C.H. Factors controlling copper solubility and chalcopyrite deposition in the Sungun porphyry copper deposit, Iran. Miner. Depos. 1999, 34, 770-783. [CrossRef]

93. Fournier, R.O. Hydrothermal processes related to movement of fluid from plastic into brittle rock in the magmatic-epithermal environment. Econ. Geol. 1999, 94, 1193-1211. [CrossRef]

94. Ohmoto, H. Systematics of sulfur and carbon isotopes in hydrothermal ore deposits. Econ. Geol. 1972, 67, 551-578. [CrossRef]

95. Sawkins, F.J. Sulfide ore deposits in relation to plate tectonics. J. Geol. 1972, 80, 377-397. [CrossRef]

96. Benedezú, R.; Fonteboté, L. Cordilleran Epithermal Cu-Zn-Pb-(Au-Ag) Mineralization in the Colquijirca District, Central Peru: Deposit-Scale Mineralogical Patterns. Econ. Geol. 2009, 104, 905-944. [CrossRef]

97. Kissin, S.A.; Mango, H. Silver vein deposits. In Treatise on Geochemistry, 2nd ed.; Elsevier: Oxford, UK, 2014; pp. 425-432.

98. Aitchison, J.C.; Xia, X.; Baxter, A.T.; Ali, J.R. Detrital zircon U-Pb ages along the Yarlung-Tsangpo suture zone, Tibet: Implications for oblique convergence and collision between India and Asia. Gondwana Res. 2011, 20, 691-709. [CrossRef]

99. Zhang, J.J.; Santosh, M.; Wang, X.X.; Guo, L.; Yang, X.; Zhang, B. Tectonics of the northern Himalaya since the India-Asia collision. Gondwana Res. 2011, 20, 939-960. [CrossRef]

100. Xu, Z.Q.; Yang, J.S.; Li, H.B.; Zhang, J.X.; Wu, C.L. Orogenic Plateau-Terrane Amalgamation, Collisional Orogeny and Uplifting of the Qinghai-Tibet Plateau; Geological Publishing House: Beijing, China, 2007. (In Chinese)

(C) 2019 by the authors. Licensee MDPI, Basel, Switzerland. This article is an open access article distributed under the terms and conditions of the Creative Commons Attribution (CC BY) license (http://creativecommons.org/licenses/by/4.0/). 